\author{
MAREK BOGDAN KOZUBEL \\ https://orcid.org/0000-0002-8096-0014 \\ Instytut Pamięci Narodowej, Warszawa
}

\title{
DZIAŁALNOŚĆ NADZWYCZAJNEJ KOMISJI ŚLEDCZEJ DS. ANTYSEMICKICH POGROMÓW NA TERYTORIUM UKRAIŃSKIEJ REPUBLIKI LUDOWEJ W 1919 ROKU
}

Abstrakt: Rok 1919 zapisał się bardzo krwawo w relacjach ukraińsko-żydowskich. Na marginesie konfliktów zbrojnych, które musiała toczyć Ukraińska Republika Ludowa, oraz przy rozpowszechnieniu bandytyzmu doszło na jej terytorium do wielu zbrodni na ludności żydowskiej. Pogromy pochłonęły życie nawet kilkudziesięciu tysięcy osób. Powyższy temat jest zdecydowanie najbardziej kontrowersyjnym fragmentem historii ukraińskiej rewolucji narodowej lat 1914-1923.

Słowa kluczowe: historia Ukrainy, pogromy, Symon Petlura, Ukraińska Republika Ludowa, zbrodnie wojenne.
Abstract: In Ukrainian-Jewish relations, the year 1919 was marked with blood. On the margin of armed conflicts fought by the Ukrainian People's Republic and widespread banditry, many crimes against Jewish people were committed in its territory. The pogroms took the lives of as many as tens of thousands people. This topic is by far the most controversial fragment of the history of the Ukrainian national revolution of 1914-23.

Keywords: history of Ukraine, pogroms, Symon Petlyura, Ukrainian People's Republic, war crimes.

Tematem artykułu są prace Nadzwyczajnej Komisji śledczej ds. Zbadania Antysemickich Pogromów na Terytorium Ukraińskiej Republiki Ludowej (URL) w 1919 r. Powyższe zagadnienie stanowi część obszernego i kontrowersyjnego problemu antyżydowskich zbrodni dokonanych na Ukrainie w 1919 r. oraz reakcji władz ukraińskich na prześladowanie mniejszości żydowskiej.

Spośród ukraińskich historyków tematem pogromów zajął się głównie Wołodymyr Serhijczuk (Volodimir Sergìjǔuk). Wymienić należy jego trzy 
wydawnictwa źródłowe, opatrzone obszernymi komentarzami. Powyższe pozycje zawierają wiele interesujących dokumentów, głównie z ukraińskich archiwów. Nie są to jednak prace pozbawione pewnych wad. Szczególnie dotyczy to stronniczych komentarzy Serhijczuka ${ }^{1}$. Znacznie bardziej wyważone są niezwykle cenne opracowania Tarasa Hunczaka (Taras Gunčak) ${ }^{2}$ i Serhija Jekelczyka (Sergiǰ Êkel'čik) ${ }^{3}$. W artykule naukowym drugiego z nich, skupiającym się na stosunku naczelnego atamana sił zbrojnych URL Symona Petlury (Simon Petlûra) do pogromów, poruszono także temat Nadzwyczajnej Komisji śledczej. W pracach pozostałych ukraińskich historyków zajmujących się tematyką I ukraińskiej rewolucji narodowej lat 1914-1921 zagadnienie pogromów było sporadycznie i niezbyt obszernie opisywane, nie mówiąc już o działalności wspomnianej Komisji. Dotyczy to również wartościowego opracowania Jurija Mitrofanenki (Ûrǐ Mìtrofanenko), analizującego zjawisko atamańszczyzny w okresie rządów Dyrektoriatu ${ }^{4}$.

Historiografię żydowską na temat pogromów można chronologicznie podzielić, zgodnie z sugestią Henry'ego Abramsona, kanadyjskiego historyka pochodzenia żydowskiego, na cztery grupy 5 . Pierwszą były opracowania wydane przed morderstwem Petlury 25 maja 1926 r., którego dokonał Sloma Szwarcbard, zamachowiec związany ze Zjednoczonym Państwowym Zarządem Politycznym (Объединённое Государственное Политическое Управление, Ob"edinënnoe Gosudarstvennoe Političeskoe Upravlenie - OGPU). Charakteryzowały się one wyważonym opisem tragicznych wydarzeń z lat 1917-19216. Zamach na Petlurę oraz proces jego mordercy spowodowały znaczącą zmianę narracji w publikacjach żydowskich. Od tego momentu pełną odpowiedzialność za pogromy na Ukrainie zrzucano na ukraińskie władze, głównie na Petlurę. W nowej fali opracowań przeważnie brakowało wzmianek na temat reakcji Dyrektoriatu na pogromy lub wręcz oskarżano go o organizowanie masakr. Zdarzały się również przypadki manipulowania cytatami i celowego

1 В. Сергійчук, Погроми в Україні: 1914-1920. Від штучних стереотипів до гіркої правди, приховуваної в радянських архівах, Київ 1998; idem, Симон Петлюра і єврейство, Київ 2006; Проскурівський погром 1919 року в документах: міфи та реальність, red. В. Сергійчук, О. Завалюк, В. Байдич, Ю. Олійник, В. Галатир, Хмельницький 2019.

${ }^{2}$ T. Hunczak, Symon Petliura and the Jews. A Reappraisal, Lviv-New York-Toronto 2008.

${ }^{3}$ С. Єкельчик, Трагічна сторінка Української революизії. Симон Петлюра та єврейські погроми в Україні (1917-1920), w: Симон Петлюра та українська національна революція. Збірник працьь другого конкурсу петлюрознавцзів України, red. В. Михальчук, Київ 1995.

${ }^{4}$ Ю. Мітрофаненко, Українська отаманщина 1918-1919 років, Кропивницький 2016.

${ }^{5}$ Г. Абрамсон, Молитва за владу. Українц̧і та євреї під час революиії (1917-1920), Київ 2017, s. 272-279.

${ }^{6}$ Zob. choćby: E. Heifetz, The Slaughter of the Jews in the Ukraine in 1919, New York 1921. 
pomijania dokumentów oraz relacji przeczących tezie o skrajnie antysemickiej postawie władz ukraińskich. Tragedia Holocaustu jeszcze bardziej scementowała poglądy historyków i publicystów żydowskich na temat stosunku władz URL do pogromów, przyczyniając się do powstania nowej grupy opracowań7.

Krokiem naprzód okazały się monografie publikowane po zakończeniu zimnej wojny. Upadek ZSRS pozwolił wielu badaczom z Zachodu na zapoznanie się z zasobami archiwów państw posowieckich, co przyczyniło się do znaczącej korekty poglądów na temat stosunku władz URL wobec Żydów. Przykładowo wspomniany już Abramson ukazał w swej monografii bardziej złożony obraz sytuacji na Ukrainie w latach 19171921. Niestety również w jego opracowaniu jedynie zasygnalizowano fakt utworzenia Komisji śledczej, będącej tematem mojego artykułu8 .

Wiele cennych informacji oraz przemyśleń na temat pogromów na Ukrainie oraz w innych częściach rozpadającego się Imperium Rosyjskiego czytelnik może znaleźć w pracach autorów zachodnich oraz rosyjskich. Opisania tego kontrowersyjnego zagadnienia podjęli się Oleg Budnicki, Manus Midlarski oraz autorzy opracowania zbiorowego'.

W historiografii polskiej można znaleźć jedynie niewielką liczbę książek zawierających informacje o pogromach na Ukrainie ${ }^{10}$. Temat ten jest przeważnie pomijany lub opisywany bardzo tendencyjnie, nierzadko $\mathrm{w}$ połączeniu $\mathrm{z}$ ignorowaniem bogatej literatury przedmiotu w postaci zagranicznych opracowań i wydawnictw źródłowych. Skutkuje to bardzo często formułowaniem krzywdzących i nieuzasadnionych tez na temat stosunku władz ukraińskich i samego Petlury do pogromów. Jednym z przykładów takiego pisarstwa historycznego jest bardzo słaba merytorycznie książka Andrzeja Kowalczyka ${ }^{11}$. Próżno jednak szukać w opracowaniach polskich historyków wzmianek na temat Nadzwyczajnej Komisji Śledczej. Koncentrowali się oni głównie na zagadnieniach politycznych i militarnych oraz losach ludności polskiej nad Dnieprem.

${ }^{7}$ Zob. np. S.S. Friedman, Pogromchik. The Assasination of Simon Petlura, New York 1976.

${ }^{8}$ Г. Абрамсон, op. cit.

9 О. Будницкий, Российские Евреи между Красными и Белыми (1917-1920), Москва 2005. Powyższe opracowanie zostało również opublikowane w j. angielskim: O. Budnitskii, Russian Jews between Whites and Reds 1917-1920, Philadelphia 2012; M. Midlarsky, The Killing Trap. Genocide in the Twentieth Century, Cambridge 2005; Anti-Jewish Violence. Rethinking the Pogrom in East European History, red. J. Dekel-Chen, D. Gaunt, N.M. Meir, I. Bartal, Bloomington 2010.

10 Zob. m.in. J.J. Bruski, Petlurowcy. Centrum Państwowe Ukraińskiej Republiki Ludowej na wychodźstwie (1919-1924), Kraków 2000, s. 65; G. Skrukwa, Formacje wojskowe ukraińskiej „rewolucji narodowej” 1914-1921, Toruń 2008, s. 408-409.

11 A. Kowalczyk, Pan Petlura?, Warszawa 1998. 
Moim celem jest przedstawienie działalności Nadzwyczajnej Komisji Śledczej w oparciu o obszerne zasoby archiwów ukraińskich ${ }^{12}$ oraz nieliczne opracowania naukowe, w których poruszono temat prac tej instytucji. Wiele dokumentów z zasobów Centralnego Państwowego Archiwum Wyższych Organów Władzy i Administracji Ukrainy w Kijowie (Central'niǰ Deržavniǰ Arhìv Viŝih Organìv Vladi ta Upravlìnnâ Ukraïni u Kiêvì) i Centralnego Państwowego Archiwum Organizacji Społecznych w Kijowie (Central'niǰ Deržavniǰ Arhìv Gromads 'kih Obêdnan` Ukraïni u Kiêvì) nie zostało wcześniej opracowanych i wykorzystanych. Bardzo wiele cennych informacji i ciekawych interpretacji wnosi również wspomniany artykuł Jekelczyka.

\section{Powstanie Dyrektoriatu i reaktywacja URL}

Po rewolucji lutowej w 1917 r. rozpoczął się proces rozpadu terytorialnego państwa rosyjskiego. Liczne mniejszości narodowe zamieszkujące Imperium Romanowów zaczęły domagać się autonomii, a nawet niepodległości. Jedną z nich byli Ukraińcy. Wiosną 1917 r. ukraińscy intelektualiści stworzyli Centralną Radę, która od tej pory była organem reprezentującym naród ukraiński w relacjach z rosyjskim Rządem Tymczasowym. Świeżo upieczone władze ukraińskie chciały stworzyć republikę z ustrojem demokratycznym i autonomią kulturalną dla mniejszości narodowych licznie zamieszkujących Ukrainę ${ }^{13}$. Po rewolucji październikowej władzę w Rosji przejęli bolszewicy, którzy na początku 1918 r. wysłali przeciwko Ukraińskiej Republice Ludowej jednostki wojskowe, celem obalenia władz demokratycznych i ustanowienia marionetkowego, sowieckiego rządu. 25 stycznia władze URL przyjęły IV Uniwersał Centralnej Rady, w którym proklamowano niepodległość państwa ukraińskiego ${ }^{14}$. Dokument został odrzucony lub zignorowany przez deputowanych reprezentujących mniejszości narodowe nad Dnieprem,

${ }^{12}$ W przypadku przypisów odsyłających do ukraińskich źródeł archiwalnych, które nie posiadają swego tytułu, podałem w opisie rodzaj dokumentu (np. list, raport), nadawcę i adresata, numer (w przypadku rozkazów lub raportów) i kolejno datę stworzenia oraz numer kartki. Wyjątek stanowią dokumenty w języku ukraińskim i rosyjskim, które mają swoje tytuły. Po wymienieniu numerów zespołu, inwentarza i teczki podałem ich tytuł w języku oryginału, a następnie datę (o ile nie pojawiła się ona już w tytule) i numer karty.

13 Szerzej: Г. Абрамсон, op. cit., s. 79-114.

14 Четвертий Універсал Української Центральної Ради, 9 I 1918, w: Українська Центральна Рада. Документи і матеріали. У двох томах, t. 2: 10 грудня 1917 р. - 29 квітня 1918 p., oprac. В. Верстюк та ін., Київ 1997, s. 102-104. 
poza polskimi politykami. Dla Ukraińców szczególnie niezrozumiała i bolesna była postawa reprezentantów żydowskich partii politycznych, którzy niekiedy demonstracyjnie występowali przeciwko ukraińskiej niepodległości. Część z nich traktowała URL jako byt tymczasowy i oportunistycznie zaczęła sympatyzować z nadchodzącymi Sowietami ${ }^{15}$.

Dalszy przebieg wojny ukraińsko-sowieckiej okazał się jednak niekorzystny dla bolszewików. Ukraińskie siły zbrojne rozgromiły zbolszewizowane formacje armii rosyjskiej na Wołyniu i Podolu, a komunistyczne powstanie w Kijowie zostało krwawo stłumione. Losów wojny nie zmieniło nawet wkroczenie - należy dodać, że z opóźnieniem i ciężkimi stratami - oddziałów sowieckich do stolicy URL ${ }^{16} .9$ lutego 1918 r. URL podpisała traktat w Brześciu Litewskim, na mocy którego stała się sojusznikiem państw centralnych (zwanych również czwórprzymierzem): II Rzeszy, Austro-Węgier, Imperium Osmańskiego i Królestwa Bułgarii. Skutkami zawarcia traktatu były udany antybolszewicki pochód wojsk niemieckich i austro-węgierskich, ale również konieczność zrealizowania zobowiązania, które przyjęła w Brześciu Litewskim delegacja Centralnej Rady - dostarczenia ogromnej ilości prowiantu (głównie zboża) ${ }^{17}$.

Liczne problemy z wypełnieniem powyższego zobowiązania oraz porewolucyjny i powojenny chaos na Ukrainie, z którymi również nie były w stanie natychmiast uporać się władze URL, skłoniły Niemców do szukania zastępstwa dla Centralnej Rady. Ostatecznie zdecydowano się na poparcie gen. Pawła Skoropadskiego (Pavlo Skoropads'kì̄) ${ }^{18}$, jednego z głównych twórców zwycięstwa nad bolszewikami. Przy życzliwej neutralności wojsk niemieckich, dokonał on 29 kwietnia 1918 r. zamachu stanu i proklamował powstanie Państwa Ukraińskiego ${ }^{19} \mathrm{w}$ miejsce URL.

${ }^{15}$ Г. Абрамсон, op. cit., s. 114-115; G. Liber, Wojny totalne i kształtowanie się wspótczesnej Ukrainy 1914-1954, Kraków 2019, s. 87.

16 Szerzej: Я. Тинченко, Українські зброцнні сили. Березень 1917-листопад 1918 p. (організація, чисельність, бойові діі), Київ 2009, s. 22-29.

17 Мирний договір міжк Німеччиною, Туреччиною, Австро-Угорщиною, Болгарією та Українською Народною Республікою, 27 I 1918 oraz Текст додаткового договору міх УНР і країнами Четверного Союзу, 27 I 1918, w: Українська Центральна Рада, t. 2, s. 137-150; M.B. Kozubel, Przestępczość w Państwie Ukraińskim w okresie koniec lipca - sierpień 1918 r. analiza na podstawie wybranych materiałów Centralnego Państwowego Archiwum Wyższych Organów Władzy i Administracji Ukrainy w Kijowie, SDRE 54, 2019, 2, s. 111.

18 Pawło Skoropadski (1873-1945) - generał armii rosyjskiej i ukraińskiej, arystokrata i hetman Państwa Ukraińskiego. Jego postaci poświęconych jest wiele opracowań, zob. m.іn.: Г. Папакін, Павло Скоропадський. Патріот, державотвореи̧ь, людина. Історико-архівні нариси, Київ 2003.

19 Temat władz centralnych, sądownictwa oraz wojska Państwa Ukraińskiego był wielokrotnie opisywany przez historyków, m.in.: Українська Держкава (квітень - грудень 
Zostało z czasem uznane przez 30 innych państw. Skoropadski przyjął tytuł hetmana i posiadał $\mathrm{w}$ zasadzie autorytarne uprawnienia ${ }^{20}$.

Władze Państwa Ukraińskiego nie cieszyły się popularnością większości przedstawicieli społeczeństwa ukraińskiego. Skoropadski otaczał się przeważnie wojskowymi i politykami narodowości rosyjskiej lub zrusyfikowanymi Ukraińcami (określającymi się jako Małorusini), prowadził bardzo konserwatywną politykę wewnętrzną i przyzwalał na rozciągnięcie jurysdykcji sądownictwa wojskowego państw centralnych na Ukrainie $^{21}$. Przeciwko władzom Państwa Ukraińskiego wybuchały liczne bunty, a sympatie ludności zaczęły przechylać się na korzyść partii skrajnie lewicowych, w tym bolszewików. Do tłumienia powstań antyhetmańskich coraz częściej angażowano żołnierzy niemieckich i austro-węgierskich. Trwałość nowych władz nad Dnieprem była zatem mocno uzależniona od powodzenia państw centralnych na frontach I wojny światowej. Pod wpływem wieści o zawieszeniu broni na froncie zachodnim 11 listopada 1918 r., hetman proklamował federację Państwa Ukraińskiego z „białą” Rosją22.

Powyższe wydarzenia pchnęły ukraińskich republikanów i socjalistów do ogłoszenia ogólnoukraińskiego powstania przeciwko Skoropadskiemu. Na czele rebelii stanął tzw. Dyrektoriat URL, który utworzono 13 listopada 1918 r. Był to organ władzy wykonawczej, w składzie

1918 року). Документи і матеріали. У двох томах, t. 1 і 2, орrac. В. Смолій, Київ 2015; Д. Дорошенко, Історія України 1917-1923 рр., t. 2: Українська Гетьманська Держкава 1918 р., Київ 2002; Д. Яневський, Проект „Україна” або спроба Павла Скоропадського, Харків 2010; Р. Пиріг, Українська гетманська держава 1918 року. Історичні нариси, Київ 2011; Я. Тинченко, Війська Ясновельможного Пана Гетьмана. Армія Української Держави, травень-грудень 1918 року, Київ 2014.

20 № 1. Грамота П. Скоропадського до всього українського народу, 29 IV 1918, oraz № 2. Закони про тимчасовий державний устрій Української Держави, 29 IV 1918, w: Українська Держава, t. 2, s. 37-42; W. Mędrzecki, Niemiecka interwencja militarna na Ukrainie w 1918 roku, Warszawa 2000, s. 157-159; О. Рум'янцев, Судова система в Українській державі гетьмана П. Скоропадського, „Вісник Академії правових наук України” 2001, 2 (25), s. 77-87; Ю. Терещенко, Гетьманат Павла Скоропадського як прояв консервативної революиії, w: Гетьманат Павла Скоропадського. історія, постаті, контроверсії. Всеукраїнськанаукова конференція 19-20 травня 2008 р., red. В. Верстюк, Київ 2008, s. 21; M.B. Kozubel, Przestępczość w Państwie, s. 112.

${ }^{21}$ Więcej informacji na temat rozciągnięcia jurysdykcji sądów wojskowych armii Państw Centralnych na terytorium Państwa Ukraińskiego: M.B. Kozubel, 0 relacjach między sądownictwem Państwa Ukraińskiego a sądami wojskowymi armii Państw Centralnych na Ukrainie w 1918 roku, w: Pogranicza w historii prawa i myśli polityczno-prawnej, red. P. Dąbrowski, D. Szpoper, Gdańsk-Olsztyn 2017, s. 355-368.

22 № 27. Грамота Гетьмана П. Скоропадського до всіх українських громадян та козаків, w: Українська Держава, t. 2, s. 68-69. 
którego zasiedli: Wołodymyr Wynnyczenko (Volodìmìr Vinničenko) ${ }^{23}$ jako przewodniczący, Symon Petlura jako Naczelny Ataman Armii URL, Andrij Makarenko (Andrij Makarenko) ${ }^{24}$, Panas Andrijewski (Panas Andrî̀vskì̌j) ${ }^{25}$ i Fedir Szwec (Fedìr Švec') ${ }^{26}$. Ogólnoukraińskie powstanie przeciwko Skoropadskiemu wybuchło 16 listopada 1918 r. Szybko ogarnęło całą Ukrainę, a terytorium kontrolowane przez hetmana skurczyło się do samego tylko Kijowa. Wpływ na błyskawiczne i spektakularne sukcesy powstańców miały masowe przejście całych oddziałów armii Państwa Ukraińskiego na stronę Dyrektoriatu oraz bierność wojsk niemieckich i austro-węgierskich. 14 grudnia 1918 r. Skoropadski zrzekł się władzy i zbiegł z Kijowa wraz z ostatnimi oddziałami niemieckimi ${ }^{27}$. Władze odrestaurowanej republiki musiały się jednak szybko zmierzyć z zagrożeniami zewnętrznymi w postaci nowej inwazji Rosji Sowieckiej, wojną z odrodzoną Polską o Wołyń i z groźbą konfliktu z Siłami Zbrojnymi Południa Rosji (SZPR) ${ }^{28}$. Tymczasem na zapleczu wojsk ukraińskich borykano się z problemem chaosu, bandytyzmu oraz samowoli wielu atamanów, dowódców oddziałów nieregularnych.

${ }^{23}$ Wołodymyr Wynnyczenko (1880-1951) - ukraiński pisarz i polityk. Pierwszy przewodniczący Dyrektoriatu URL. W styczniu 1919 r. podał się do dymisji, Директорія, Рада Народних Міністрів Української Народної Республіки 1918-1920. Документи і матеріали у 2 томах, t. 1, red. В. Верстюк, Київ 2006, s. 611.

${ }^{24}$ Andrij Makarenko (1885-1963) - ukraiński polityk. Jeden z członków Dyrektoriatu. W grudniu 1919 r. został wysłany przez Petlurę z misją dyplomatyczną do państw Europy Zachodniej, ibidem.

${ }^{25}$ Panas Andrijewski (1878-1955) - ukraiński polityk. Jeden z członków Dyrektoriatu. Podał się do dymisji w kwietniu 1919 r. z powodu wybrania na premiera Borysa Martosa, ibidem, s. 615.

${ }^{26}$ Fedir Szwec (1882-1940) - ukraiński polityk. Jeden z członków Dyrektoriatu. W grudniu 1919 r. został wysłany przez Petlurę z misją dyplomatyczną do państw Europy Zachodniej, ibidem, s. 611.

${ }^{27} \mathrm{Na}$ temat tej insurekcji oraz pozostałych buntów przeciwko hetmanowi, szerzej: W. Mędrzecki, op. cit., passim; G. Skrukwa, op. cit., s. 343-361; Р. Пиріг, Т. Осташко, Гетьманська Держава, w: Нариси історії Української Революиії 1917-1921 років, t. 1, red. В. Смолій, Київ 2011, s. 348-371; В. Резніков, Антигетьманський повстанський рух на Слобожанщині (травень-листопад 1918 року), „Молодий вчений”, май 2015, 5 (20), cz. 1, s. 77-83; idem, Селянський повстанський рух на Слобожанщзині (березень 1918-1923 рр.), w: Війна з державою чи за державу? Селянський повстанський рух в Україні 1917-1921 років, red. В. Лободаєв, Харків 2017, s. 326-328.

${ }^{28}$ Siły Zbrojne Południa Rosji - zbrojne ramię rządu Południa Rosji, z siedzibą w Sewastopolu. Stanowiły część tzw. Białej Rosji podczas wojny domowej 1917-1922. Dowódcą SZPR był gen. Anton Denikin. W 1920 r. zastąpił go gen. Piotr Wrangel (Pëtr Vrangel), Вооружсенные силы на Юге Росии, red. С. Волков, Москва 2003; Р. Абинякин, Офицерский корпус Добровольческой Армии: социальный состав, мировоззрение. 1917-1920 г2., Орел 2005; П. Кенез, Подлинная история Добровольческой армии 1917-1918, Москва 2017, passim. 
Pogromy na terytorium kontrolowanym przez Dyrektoriat URL

W okresie grudzień 1918 r. - grudzień 1919 r. przez ukraińskie ziemie maszerowały formacje Armii Czynnej URL, Armii Czerwonej, Sił Zbrojnych Południa Rosji, Wojska Polskiego, a także oddziały niezależnych atamanów, m.in. Matwieja Grigoriewa (Matvêj Grigor'êv) ${ }^{29}$ i Nestora Machno (Nestor Mahno) ${ }^{30}$. Ponadto na wybrzeżu Morza Czarnego wylądował korpus ekspedycyjny Ententy ${ }^{31}$. Działania wojenne na terenie dawnego Imperium Rosyjskiego, w tym na Ukrainie, charakteryzował niespotykany dotąd terror wobec ludności cywilnej, liczne grabieże oraz zbrodnie wojenne. George Liber zwraca uwagę na to, że w wyniku konfliktów zbrojnych nad Dnieprem w latach 1917-1921 liczba ofiar cywilnych sięgnęła 2,3 $\mathrm{mln}$ osób ${ }^{32}$.

W okresie wojny domowej na terenie dawnego Imperium Rosyjskiego częste były pogromy ludności żydowskiej. Na Ukrainie według Olega Budnickiego w latach 1918-1920 doszło do ok. 1500 pogromów w ponad 1300 miejscowościach. Życie miało stracić od 50 do 200 tys. osób, dziesiątki tysięcy kobiet zostały wdowami, a 300 tys. dzieci sierotami. Ponadto zgwałcono tysiące żydowskich kobiet. W tradycji żydowskiej za najkrwawszy okres uznano rok 1919. Według wczesnych szacunków wkład poszczególnych sił w pogromy na Ukrainie w 1919 r. miał być następujący: oddziały podporządkowane Dyrektoriatowi URL wymordowały 16706 Żydów (54 proc. ofiar śmiertelnych), „biali” (głównie SZPR) 5235 (16,9 proc.), niezależnie oddziały atamanów i bandy chłopskie lub kryminalne 4615 (14,9 proc.), oddziały atamana Grigoriewa 3471 (11,2 proc.), Sowieci 725 (2,3 proc.), polskie formacje wojskowe i paramilitarne 134 (0,4 proc.), a nieustalone grupy 36 osób ( 0,1 proc.). Dyrektoriat miał odpowiadać za 439 pogromów (40 proc.), niezależne oddziały atamanów i bandy

${ }^{29}$ Matwiej Grigoriew (1885-1919) - rosyjsko-ukraiński wojskowy i zbrodniarz wojenny. W 1918 r. poparł powstanie Dyrektoriatu przeciwko hetmanowi Skoropadskiemu. Na początku 1919 r. opowiedział się do stronie Sowietów i na czele swych oddziałów zaatakował wojska Ententy, które wylądowały w okolicach Odessy. Wiosną 1919 r. zbuntował się przeciwko bolszewikom. Został zamordowany z rozkazu atamana Nestora Machny. Znany był również jako Nikifor Grigoriew, Я. Тинченко, Офіųерський корпус Армії Української Народної Республіки (1917-1921), t. 1, Київ 2007, s. 122.

30 Nestor Machno (1888-1934) - ukraiński anarchista i ataman wojsk powstańczych. Znany z walki z wszelką władzą na południu Ukrainy, „białymi”, bolszewikami, ukraińskimi republikanami i wojskami Państw Centralnych. Po klęsce militarnej wyemigrował do Polski i następnie do Francji, В. Савченко, Махно, Харків 2005, passim.

${ }^{31}$ J.J. Bruski, op. cit., s. 61.

${ }^{32}$ G. Liber, op. cit., s. 5. 
chłopskie/kryminalne 307 (25 proc.), SZPR i inne „białe” formacje za 213 (17 proc.), Sowieci 106 (9 proc.), oddziały atamana Grigoriewa 52 (4 proc.), nieustalone grupy za 33 ( 3 proc.), a Polacy za 32 pogromy (3 proc.) ${ }^{33}$.

$\mathrm{Na}$ terytorium kontrolowanym przez Dyrektoriat URL pogromów dokonywały przeważnie oddziały niezdyscyplinowanych watażków, zwanych atamanami. Dowodzili oni formacjami o zróżnicowanej liczebności i skuteczności bojowej. Niejednokrotnie dochodziło do sytuacji, gdy bez uzasadnienia określali swe oddziały „pułkami” lub „dywizjami”, co miało sugerować, iż w ich skład wchodzi wiele tysięcy żołnierzy. Sami sobie nadawali stopnie „sotnyków” (kapitanów), „pułkowników” czy najczęściej właśnie „atamanów”. Ostatni z wymienionych stopni był ukraińsko-rewolucyjnym odpowiednikiem generała. Nawiązywał do tradycji Kozaków zaporoskich, do których zresztą niektórzy watażkowie upodabniali się również ubiorem i sposobem utrzymywania dyscypliny. Z czasem jednak początkowo popularny tytuł atamana „zyskał” pod wpływem działalności watażków negatywne znaczenie ${ }^{34}$.

W pierwszych miesiącach po obaleniu Skoropadskiego władze URL dysponowały niewielkimi siłami regularnymi ${ }^{35}$. Z tego powodu starały się wykorzystać atamanów zarówno na polu walki, jak i w terenie w charakterze komendantów, mających tymczasowo zastąpić władze lokalne. Poszczególni watażkowie zajmowali terytorium obejmujące najczęściej jeden lub kilka powiatów, a następnie wprowadzali tam swego rodzaju autonomiczną władzę. Uparcie odmawiali przy tym wykonywania większości rozkazów dowódców dywizji lub korpusów, którym zostały podporządkowane ich oddziały, a nawet ignorowali telegramy płynące ze Sztabu Armii Czynnej URL. Dotyczyło to szczególnie rozkazów wyjścia na front antysowiecki. Bywało, że atamanowie samowolnie opuszczali strefę działań wojennych. Na tyłach wojsk ukraińskich najczęściej prowadzili grabież i terroryzowali ludność cywilną. Zgoda watażków na takie działania podwładnych niejednokrotnie była podyktowana chęcią utrzymania

33 О. Будницкий, op. cit., s. 276-277. Zdaniem Manusa Midlarskiego dzięki ułatwieniu dostępu do zasobów rosyjskich archiwów po 1991 r. można znacząco skorygować szacunki dotyczące wkładu poszczególnych stron konfliktu w pogromy. Ocenia on, że SZPR mogą odpowiadać za śmierć nawet 50 proc. Żydów zamordowanych na Ukrainie w 1919 r., M. Midlarsky, op. cit., s. 45.

${ }^{34}$ М. Капустянський, Похід українських армій на Київ-Одессу в 1919 роизі, w: Україна. 1919 рік. М. Капустянський „Похід українських армій на Київ-Одессу в 1919 році””. Є. Маланюк „Уривки зі спогадів”. Документи та матеріали, red. Я. Тинченко, Київ 2004, s. 72; Ю. Мітрофаненко, op. cit., s. 89-90.

35 Szerzej: M. Krotofil, Siły Zbrojne Ukraińskiej Republiki Ludowej (listopad 1918 r. grudzień 1919 r.), Kijów 2011, s. 37-66; Є. Пінак, М. Чмир, Військо Української революції 1917-1921 років, Харків 2017, s. 82-91. 
swej popularności w ich oczach, obok rzecz jasna woli zaspokojenia własnych żądz. Wprowadzony przez nich chaos, grabieże i pogromy wywoływały niezadowolenie i drastycznie obniżały zaufanie cywilów do władz republikańskich. Atamańszczyzna, którą Petlura pragnął wykorzystać do wzmocnienia ukraińskiej państwowości oraz armii, okazała się czynnikiem destrukcyjnym w obu przypadkach ${ }^{36}$.

Najkrwawsze pogromy na terytorium URL miały miejsce głównie na przełomie 1918 i 1919 r. Pierwszą dużą zbrodnią na Żydach była zapomniana dzisiaj masakra w Żytomierzu w dniach 9-12 stycznia 1919 r. ${ }^{37}$ Najsłynniejszym zaś pogromem stała się masakra dokonana przez oddział atamana Iwana Semensenki (Ivvan Semensenko) ${ }^{38}$ w Płoskirowie 15-16 lutego 1919 r. Dzień przed rzezią Sowieci przeprowadzili tam nieudaną próbę przewrotu. Podjęły ją bojówki bolszewickie i kilkuset zdemoralizowanych żołnierzy, którzy zdradzili URL, lecz zostali oni nieoczekiwanie zmasakrowani przez zagon atamana Semensenki. Po pokonaniu „czerwonych” watażka podjął decyzję wymordowania lokalnych Żydów. Co ciekawe, zakazał przy tym jakichkolwiek rabunków. Kozacy Semensenki mieli się skupić jedynie na mordowaniu. W wyniku pogromu zginęło i zmarło od odniesionych obrażeń 1063 Żydów³. Następnego dnia

36 Ю. Мітрофаненко, ор. cit., s. 90-91, 106 і 133.

37 Я. Тинченко, Хроніка бойових дій Армії УНР проти більшовиків у грудні 1918 травні 1919 рр, w: Україна. 1919 рік, s. 362-363.

38 Iwan Semensenko (1894-1920) - ukraiński wojskowy i zbrodniarz wojenny. Był dowódcą nieregularnego oddziału wojskowego sił zbrojnych URL. Został aresztowany i pozbawiony dowództwa z powodu niewykonywania rozkazów przełożonych. W 1920 r. pojawił się w Polsce i na żądanie emigracyjnego rządu petlurowskiego został przekazany władzom ukraińskim i rozstrzelany, Я. Тинченко, ОФіцеерський корпус, s. 393-394.

39 Central'niǰ Deržavniǰ Arhìv Viŝih Organìv Vladi ta Upravlìnnâ Ukraïni u Kiêvì (dalej: ЦДАВОВУ), f. 1078, o. 1, sp. 17, „Звіт Головного Інформаційного Бюро Армії Українськ. Народ. Республики за 23-го II 1919 року”, 23 II 1919, k. 153; ЦДАВОВУ, f. 1123, op. 1, sp. 1, Raport P. Papmela do Nadzwyczajnej Komisji Śledczej ze śledztwa w sprawie pogromu w Płoskirowie, 15 XI 1919, k. 9-13; Додаток № 1. Список осіб єврейської національності, які були вбиті та померли від ран під час погрому в м. Проскурові, w: Проскурівський погром, s. 208-265. Pogrom w Płoskirowie szybko stał się obiektem licznych manipulacji, zarówno co do przebiegu masakry, jak i liczby ofiar. W jednym $\mathrm{z}$ bolszewickich raportów przedstawiono daleki od prawdy obraz pogromu w Płoskirowie. Zapisano w nim, jakoby masakrę urządzili „petlurowscy oficerowie sztabowi”. Życie miało stracić aż 6 tys. osób cywilnych, por.: № 787. Телеграмма командира Полка Червоного Казачества В.М. Примакова Совнаркому Украины о переходе отряда петлюровизев на сторону советских войск, 23 III 1919, w: Гражданская война на Украине 19181920, Сборник документов і материалов в трех томах, четырех книгах, t. 1, cz. 1, red. С.М. Короливский, Н.К. Колесник, И.К. Рыбалка, Киев 1967, s. 688. Również rzetelny badacz Oleg Budnicki zawyżył liczbę ofiar do 1650 Żydów wymordowanych „w przeciągu kilku godzin", por.: О. Будницкий, op. cit., s. 277. 
watażka zebrał swój oddział i udał się do pobliskiego Felsztyna, gdzie urządził wraz ze swymi podwładnymi kolejną masakrę. Tam wymordowanych zostało od ok. 485 do 600 osób $^{40}$.

Znaczący spadek liczby pogromów na terenie kontrolowanym przez Dyrektoriat nastąpił wraz z wykruszeniem się oddziałów nieregularnych, aresztowaniem wielu atamanów oraz utratą znacznej części terytorium. Latem 1919 r. Armia Czynna była już znacznie bardziej zdyscyplinowana i lepiej dowodzona. Odwrót na Wołyń, a następnie Podole, połączony z ewakuacją urzędników pozwolił Dyrektoriatowi na stworzenie sprawniej funkcjonującej administracji na mniejszym terytorium ${ }^{41}$. Przestępstwa wobec Żydów nadal miały miejsce, ale nie przybierały już formy wielkich masakr, jak w Płoskirowie czy Felsztynie. Poza nimi dochodziło do starć pomiędzy formacjami Armii URL a sowieckimi bojówkami złożonymi z Żydów, które z oczywistych powodów nie spełniają definicji pogromu. Przykładem takich wydarzeń były bitwy o Kamieniec Podolski na początku czerwca 1919 r. i pod Mohylewem Podolskim w lipcu 1919 r. ${ }^{42}$

Ograniczeniu liczby pogromów i innych przestępstw na Żydach sprzyjało wykorzystywanie formacji regularnych do zdobywania i obsadzania miast. Jekelczyk nazwał tę tendencję „"strategią żydowską» generała [a właściwie pułkownika - M.B.K.] Wołodymyra Salskiego [Volodimir Salskìj]"43. Ustabilizowaniu sytuacji na zapleczu oraz uspokojeniu społeczności żydowskiej sprzyjało pojawienie się na Podolu w drugiej połowie lipca 1919 r. Armii Halickiej ${ }^{44}$. Dochodziło wręcz do sytuacji, gdy Żydzi nalegali na rozlokowanie w ich miejscowościach formacji złożonych z Haliczan ${ }^{45}$.

40 ЦДАВОВУ, f. 1078, op. 1, sp. 17, „Звіт Головного Інформаційного Бюро Армії Українськ.Народ. Республики за 23-го II 1919 року”, 23 II 1919, k. 153.

${ }^{41}$ I. Крипякевич, Б. Гнатєвич, 3. Стефанів, О. Думін, С. Шрамченко, Icmopiя українського війська, Львів 1992 (reprint 1936), s. 536-537; J. Legieć, Armia Ukraińskiej Republiki Ludowej w wojnie polsko-ukraińsko-bolszewickiej w 1920 r., Toruń 2002, s. 22; S. Szajdak, Polsko ukraiński sojusz polityczno wojskowy w 1920 roku, Warszawa 2005, s. 57; G. Skrukwa, op. cit., s. 388; Є. Пінак, М. Чмир, op. cit., s. 154-169.

${ }^{42}$ ЦДАВОВУ, f. 3172, op. 3, sp. 43, Raport płk. O. Udowyczenki nr 02, 7 VI 1919, k. 4; С. Гольдельман, Жидівська національна автономія на Україні (1917-1920 рр.), Мюнхен 1963, s. 96.

43 С. Єкельчик, op. cit., s. 180.

${ }^{44}$ Więcej na temat Armii Halickiej, jej szlaku bojowego oraz wojny polsko-ukraińskiej zob.: М. Литвин, Українсько-польська війна 1918-1919 рр., Львів 1998; M. Klimecki, Lwów 1918-1919, Warszawa 1998; M. Krotofil, Ukraińska Armia Halicka 1918-1920. Organizacja, uzbrojenie, wyposażenie i wartość bojowa sił zbrojnych Zachodnio-Ukraińskiej Republiki Ludowej, Toruń 2002; О. Дєдик, Чортківська офензива, сz. 1 і 2, Львів 2015.

${ }^{45}$ С. Єкельчик, op. cit., s. 179. 
Reakcja władz centralnych URL

Omówione wyżej krwawe wydarzenia skłoniły Dyrektoriat do reakcji. Poza rozkazami mającymi wpłynąć na zwiększenie dyscypliny $\mathrm{w}$ armii i doprowadzić do ukarania winnych ${ }^{46}$ podjęto również decyzję o stworzeniu komisji śledczych mających szczegółowo zbadać problem pogromów. 3 marca 1919 r. powołano Nadzwyczajną Komisję śledczą, której celem było zbadanie zbrodni w Żytomierzu ${ }^{47}$. 9 kwietnia 1919 r. władze Dyrektoriatu, w osobach Petlury, Makarenki, Andrijewskiego i p.o. sekretarza państwowego S. Hajewskiego (S. Gaêvskiǰ), podjęły decyzję o powołaniu niezależnej komisji śledczej, której celem było przeprowadzenie śledztwa w sprawie pogromów w Płoskirowie i Felsztynie. Komisja miała funkcjonować w oparciu o statut Nadzwyczajnej Komisji Śledczej z 3 marca $^{48}$. Pod dokumentem podpisali się również zastępca premiera Iwan Feszczenko-Czopiwski (İvan Feŝenko-Čopìvs'kì̄j) ${ }^{49}$ i sekretarz państwowy Mychajło Korczynski (Mihaǰlo Korčins'kij̃) ${ }^{50}$, z zawodu adwokat.

Wielu ukraińskich polityków uznało stworzenie tej instytucji za niewystarczające do rzetelnego zbadania fali antyżydowskich zbrodni oraz

${ }^{46}$ Szerzej m.in. ЦДАВОВУ, f. 1075, op. 1, sp. 16, „Наказ Головної Управи Війська Української Народної Республики ч. 72”, 19 I 1919, k. 3; ЦДАВОВУ, f. 1078, op. 1, sp. 6 , Telegram Naczelnego Atamana Petlury, 28 I 1919, k. 75-77; ЦДАВОВУ, f. 2060, op. 1, sp. 23, Telegram Głównego Atamana S. Petlury do komendanta stacji Myrhorod, 28 I 1919, k. 10; Телеграма Головного Отамана військ УНР Симона Петлюри коменданту станизї Миргород про заборону єврейських погромів українськими вояками, розслідування ексиесу на станиії Яреськи й карне переслідування винних, 28 I 1919, w: В. Сергійчук, Симон Петлюра, s. 99; Наказ Головного Отамана С. Петлюри про заборону посягати на народне добро, 21 ХІ 1918, Наказ Головної Команди військ УНР про введення в силу окремих статей закону про кримінальну відповідальність за антидержавну діяльність і грабежі мирного населення, 22 ХІІ 1918, w: Симон Петлюра. Статті, листи, документи, t. 4, red. М. Іщенко, Київ 2006, s. 206 і 229.

${ }^{47}$ Central'niǰ Deržavniǰ Arhìv Gromads`kih Obêdnan` Ukraïni u Kiêvì (dalej: ЦДАГОу), f. 269, op. 1, sp. 32, „Статут Надзвичайноі Слідчоі Комісії в м. Житомирі”, k. 9-10.

${ }^{48}$ ЦДАГОУ, f. 269, ор. 1, sp. 32, „Постапова про заснування окремої Слідчої Комісії для переведення слідства в справі погрому 15-16 II 1919 року в. м. Проскурові й 17 II в м. Фельштині, Проскурівського повіту", 9 IV 1919, k. 1.

${ }^{49}$ Iwan Feszczenko-Czopiwski (1884-1952) - ukraiński działacz polityczny i naukowy. Minister gospodarki w rządzie URL. W okresie międzywojennym profesor Akademii Górniczej w Krakowie. Zmarł w sowieckim obozie pracy w Republice Komi, Директорія, t. 1 , s. 618.

${ }^{50}$ ЦДАГОУ, f. 269, op. 1, sp. 32, List ministra ds. żydowskich do ministra sprawiedliwości, 22 VI 1919, k. 11. 
odstraszenia potencjalnych sprawców od dokonywania kolejnych przestępstw. Szczególnie aktywnie wypowiadał się w tej sprawie premier rządu URL Borys Martos (Boris Martos) ${ }^{51} .12$ kwietnia wydał antypogromową odezwę do narodu ukraińskiego ${ }^{52}$, a pięć dni później w liście do ministra sprawiedliwości Andrija Liwyckiego (Andrì Lìvickiǰ) ${ }^{53}$ domagał się, aby w przypadku wystąpienia kolejnych pogromów wymiar sprawiedliwości bez zwłoki wszczynał postępowania, a sprawcy zbrodni natychmiast pociągani byli do odpowiedzialności ${ }^{54}$.

Kwestia śledztw w sprawie pogromów musiała jednak zostać odłożona na później z powodu kolejnych porażek na frontach i odciągnięcia uwagi Dyrektoriatu przez inne, znacznie poważniejsze problemy wewnętrzne. $\mathrm{Na}$ domiar złego w tym samym czasie doszło do nieudanego zamachu stanu zorganizowanego przez atamana Wołodymyra Oskiłkę (Volodimir Oskìlko) ${ }^{55}$. Pomimo porażki spiskowców udało się im zrabować skarb państwa, doprowadzić do chaosu na zapleczu sił zbrojnych URL i odciągnąć część oddziałów z linii frontu. W kwietniu i maju 1919 r. Dyrektoriat utracił wołyńską część swego terytorium. Rząd został ewakuowany do Stanisławowa, gdzie mieściła się tymczasowa stolica autonomicznego Zachodniego Obwodu Ukraińskiej Republiki Ludowej ${ }^{56}$.

Armia Czynna URL również wycofała się na terytorium siostrzanej republiki i rozpoczęła odbijanie Podola z rąk bolszewików. 3 czerwca

${ }^{51}$ Borys Martos (1879-1977) - ukraiński polityk i premier rządu URL od 9 IV do 27 VIII 1919 r., Директорія, t. 1, s. 614.

52 № 273. Декларація уряду УНР. Декларація правительства Б. Мартоса, 21 IV 1919, w: Директорія, t. 2, s. 519; Г. Абрамсон, ор. cit., s. 232.

53 Andrij Liwycki (1879-1954) - ukraiński polityk, minister sprawiedliwości oraz spraw zagranicznych w trzech gabinetach Rady Ministrów URL. W 1920 r. został premierem rządu republiki na emigracji. Po zamordowaniu Petlury w 1926 r. został przywódcą URL, Директорія, t. 1, s. 623.

${ }^{54}$ ЦДАГОУ, f. 269, op. 1, sp. 32. List premiera Rządu URL Borysa Martosa do Ministra Sprawiedliwości URL, 17 IV 1919, k. 2.

55 Wołodymyr Oskiłko (1892-1926) - ukraiński wojskowy. Uczestnik powstania przeciwko Skoropadskiemu i dowódca grupy operacyjnej wojsk URL na Wołyniu. 28 kwietnia 1919 r. wystąpił przeciwko ówczesnemu rządowi URL, którym kierował premier Martos. Z powodu porażki puczu zbiegł na terytorium Polski. W 1926 r. został zamordowany, prawdopodobnie przez zabójcę wysłanego przez sowieckie służby specjalne, Я. Тинченко, Офіцеерський корпус, s. 318.

${ }^{56}$ I. Крипякевич, Б. Гнатєвич, 3. Стефанів, О. Думін, С. Шрамченко, op. cit., s. 537; J.J. Bruski, op. cit., s. 84; J. Legieć, op. cit., s. 21; S. Szajdak, op. cit., s. 56; В. Сідак, Т. Осташко, Т. Вронська, Полковник Петро Болбочан: трагедія українського державника, Київ 2009, s. 84-87; Є. Пінак, М. Чмир, ор. cit., s. 92-94. Na temat krótkiej historii Zachodnio-Ukraińskiej Republiki Ludowej, przemianowanej w styczniu 1919 r. na Zachodni Obwód URL zob. С. Макарчук, Українська Республіка Галичан, Львів 1997. 
1919 r. Ukraińcy wyzwolili Kamieniec Podolski, gdzie z czasem przeniosły się władze Dyrektoriatu ${ }^{57}$. Kolejne sukcesy wojsk ukraińskich doprowadziły do przejęcia inicjatywy na froncie z rąk Armii Czerwonej oraz stworzenia dosyć dużego i bezpiecznego zaplecza dla Armii URL. Stabilizacji sprzyjała koncentracja zdyscyplinowanych formacji wojskowych, wykruszenie się większości nieregularnych oddziałów, a także proces tworzenia nowej administracji ${ }^{58}$.

\section{Powstanie Nadzwyczajnej Komisji Śledczej ds. Antysemickich Pogromów}

W tym samym czasie, dzięki chwilowej stabilizacji, władze URL znowu podjęły się zmierzenia z tematem pogromów oraz ustalenia personaliów sprawców celem wymierzenia sprawiedliwości. 27 maja 1919 r. przyjęto ustawę o utworzeniu Nadzwyczajnej Komisji śledczej ds. Zbadania Pogromów Antysemickich na terytorium URL. Informację o jej uchwaleniu ogłoszono drogą telegraficzną. Proces wyboru jej przewodniczącego wyglądał następująco: kandydata miał wskazać minister sprawiedliwości, po czym rząd przedstawiał go Dyrektoriatowi, a ten organ wykonawczy uroczyście desygnował go na to stanowisko. Ponadto pięć ministerstw przedstawiało swoich kandydatów, po jednym z każdego resortu, na członków kierownictwa Komisji. Sprawy, które miała rozpatrywać nowo powołana instytucja, przekazywał Komisji Minister Sprawiedliwości w porozumieniu z ministrem ds. żydowskich Pinchasem Krasnym (Pìnhas Krasniǰ $)^{59}$.

Do zadań Komisji należało:

- prowadzenie wszechstronnych śledztw w sprawie antyżydowskich pogromów i antyżydowskiej agitacji na terytorium URL;

57 ЦДАВОВУ, f. 3172, op. 3., sp. 43, Raport płk. Ołeksandra Udowyczenki nr 02, 7 VI 1919, k. 4; О. Удовиченко, Третя Залізна дивізія. Матеріяли до історії Війська Української Народної Республики. Рік 1919, Ню-Йорк 1971, s. 32-35; М. Капустянський, op. cit., s. 99 і 129; Я. Тинченко, Хроніка, s. 483-484.

${ }^{58}$ I. Крипякевич, Б. Гнатєвич, 3. Стефанів, О. Думін, С. Шрамченко, op. cit., s. 536-537; J. Legieć, op. cit., s. 22; S. Szajdak, op. cit., s. 57; G. Skrukwa, op. cit., s. 388; Є. Пінак, М. Чмир, оp. cit., s. 154-169.

${ }^{59}$ ЦДАВОВУ, f. 1123 , ор. 1, sp. 36, „Закон про утворення Особливої Слідчої Комісії для розслідування протиєврейських погромних подій”, 27 V 1919, k. 5; ЦДАГОУ, f. 269, ор. 1, sp. 32, „Закон про утворення Особливої Слідчої Комісії для розслідування протиєврейських погромних подій”, 27 V 1919, k. 3; Закон Директорії УНР про утворення Особливої Слідчої Комісії для розслідування єврейських погромів, 27 V 1919, w: В. Сергійчук, Симон Петлюра, s. 99-103; С. Єкельчик, op. cit., s. 184. 
- ustalenie personaliów sprawców i przekazanie protokołów do sądów wojskowych Armii Czynnej URL celem pociągnięcia winnych do odpowiedzialności karneje ${ }^{60}$.

Jak więc widać, zadania Komisji częściowo pokrywały się z kompetencjami prokuratury. Instytucja prowadziła postępowania przygotowawcze i przekazywała następnie wyniki śledztw sądom wojskowym, które miały wydać wyrok. Nie ma jednak wzmianki o udziale kierownictwa Komisji lub jej śledczych w postępowaniu sądowym - zadanie oskarżyciela zapewne przejmowali prokuratorzy wojskowi niezwiązani z Komisją śledczą.

Aby jej decyzje były prawomocne, musiało je podjąć kolegium w następującym składzie: prezes albo jego zastępca, którym był przedstawiciel ministra sprawiedliwości, sekretarz (lub jego zastępca) i nie mniej niż trzech członków Komisji. Powyższe uchwały nie podlegały zaskarżeniu, a od działań członków Komisji można było odwoływać się wyłącznie do niej samej. Nie wstrzymywało to jednak postępowania ${ }^{61}$.

Komisja miała własną kancelarię w składzie sekretarza, jego zastępcy i trzech urzędników, wyznaczonych przez szefa Komisji. Członkowie bądź osoby działające z upoważnienia Komisji do przeprowadzenia postępowań mogły wykorzystywać wszelkie uprawnienia śledczych sądowych i wojskowych oraz wykonywały swoje obowiązki zgodnie z ustawami o sądownictwie karnym i wojskowym. Ponadto Komisja miała prawo zlecać wykonanie pojedynczych zadań lub prowadzenie całych postępowań śledczym wojskowym i sądowym, a także członkom sądów okręgowych, apelacyjnych i wojskowych. Mieli być uważani za tymczasowo przydzielonych do prac Komisji ${ }^{62}$.

${ }^{60}$ ЦДАВОВУ, f. 1123, op. 1, sp. 36, „Закон про утворення Особливої Слідчої Комісії для розслідування протиєврейських погромних подій”, 27 V 1919, k. 5; ЦДАГОУ, f. 269, ор. 1, sp. 32, „Закон про утворення Особливої Слідчої Комісії для розслідування протиєврейських погромних подій”, 27 V 1919, k. 3; Закон Директорії УНР про утворення Особливої Слідчої Комісії для розслідування єврейських погромів. 27 V 1919, w: В. Сергійчук, Симон Петлюра, s. 100.

${ }^{61}$ ЦДАВОВУ, f. 1123, op. 1, sp. 36, „Закон про утворення Особливої Слідчої Комісії для розслідування протиєврейських погромних подій”, 27 V 1919, k. 5; ЦДАГОУ, f. 269, op. 1, sp. 32, „Закон про утворення Особливої Слідчої Комісії для розслідування протиєврейських погромних подій”, 27 V 1919, k. 3; Закон Директорії УНР про утворення Особливої Слідчої Комісії для розслідування єврейсъких погромів. 27 травня 1919, w: В. Сергійчук, Симон Петлюра, s. 100.

${ }^{62}$ ЦДАВОВУ, f. 1123, ор. 1, sp. 36, „Закон про утворення Особливої Слідчої Комісії для розслідування протиєврейських погромних подій”, 27 V 1919, k. 5; ЦДАГОУ, f. 269, ор. 1, sp. 32, „Закон про утворення Особливої Слідчої Комісії для розслідування протиєврейських погромних подій”, 27 V 1919, k. 3; Закон Директорії УНР про утворення Особливої Слідчої Комісії для розслідування єврейських погромів. 27 травня 1919, w: В. Сергійчук, Симон Петлюра, s. 100-101. 
Członkowie Komisji i osoby do niej przydzielone mieli prawo do dokonywania aresztowań, przeszukiwań, konfiskowania korespondencji, kontaktu z urzędnikami każdej rangi, zajmowania mienia osób podejrzanych, a także do wymagania od osób i urzędów URL wszelkiej pomocy. Komisja miała prawo do wszczęcia postępowania karnego względem urzędników wszelkiej rangi, gdyby okazało się, że uczestniczyli w pogromach. Mogła też zadecydować o tymczasowym usunięciu ich z zajmowanych urzędów. Nie rozciągało się to na pracowników sądów cywilnych i wojskowych. Urzędnicy od rangi III wzwyż mogli jednak zostać odsunięci tylko za sprawą uchwały Rady Ministrów, wskutek propozycji wniesionej przez ministra sprawiedliwości na wniosek Komisji ${ }^{63}$.

Umorzenie postępowania mogło się odbyć na skutek decyzji Komisji przy udziale nadzoru prokuratora wyznaczonego przez ministra sprawiedliwości. Umorzone sprawy wraz z postanowieniami Komisja miała zgodnie z art. 520 Kodeksu Sądownictwa Karnego przekazać odpowiedniemu wojskowemu dowódcy w randze co najmniej dowódcy korpusu. Ten na podstawie ustawy z 26 stycznia 1919 r. zwoływał nadzwyczajny sąd wojskowy do rozpatrzenia tychże spraw. W wyjątkowych okolicznościach taki sąd mógł być zwołany przez ministrów sprawiedliwości, spraw wojskowych i ds. żydowskich, a skład sądu wyznaczał Dyrektoriat po przedstawieniu kandydatur od wspomnianych wyżej ministrów. Komisja jeszcze przed pełnym zakończeniem śledztw mogła przekazać ich wyniki zaznaczonym sądom w zakresie oskarżenia pojedynczych osób ${ }^{64}$.

Nadzwyczajna Komisja Śledcza rozpoczęła prace 9 lipca 1919 r. W tym czasie Armia URL stopniowo odbijała Podole z rąk bolszewików i przygotowywała się do wspólnego z Armią Halicką marszu na Kijów i Odessę. Sukcesy na froncie i stabilizacja na zapleczu sprzyjały pracom tego organu, podobnie jak i stopniowa transformacja sił zbrojnych URL w regularne i zdyscyplinowane wojsko ${ }^{65}$.

${ }^{63}$ ЦДАВОВУ, f. 1123, op. 1, sp. 36, „Закон про утворення Особливої Слідчої Комісії для розслідування протиєврейських погромних подій”, 27 V 1919, k. 5; ЦДАГОУ, f. 269, op. 1, sp. 32, „Закон про утворення Особливої Слідчої Комісії для розслідування протиєврейських погромних подій”, 27 V 1919, k. 3; Закон Директорії УНР про утворення Особливої Слідчої Комісії для розслідування єврейських погромів. 27 травня 1919, w: В. Сергійчук, Симон Петлюра, s. 101.

${ }^{64}$ ЦДАВОВУ, f. 1123 , ор. 1, sp. 36, „Закон про утворення Особливої Слідчої Комісії для розслідування протиєврейських погромних подій”, 27 V 1919, k. 6; ЦДАГОУ, f. 269, op. 1, sp. 32, „Закон про утворення Особливої Слідчої Комісії для розслідування протиєврейських погромних подій”, 27 V 1919 року, k. 3; Закон Директорії УНР про утворення Особливої Слідчої Комісії для розслідування єврейських погромів. 27 травня 1919, w: В. Сергійчук, Симон Петлюра, s. 101-102.

${ }^{65}$ Zob. przyp. 41. 


\section{Polityka personalna Nadzwyczajnej Komisji Śledczej}

4 lipca na prezesa Nadzwyczajnej Komisji Śledczej wyznaczono z rozkazu Dyrektoriatu Mychajła Korczynskiego ${ }^{66}$. Za jego udziałem w pracach tego ciała lobbował minister ds. żydowskich w rządzie URL ${ }^{67}$.

Pozostały skład Komisji był następujący:

- ze strony Ministerstwa Sprawiedliwości: Wiktor Zawadski (Vìktor Zavads'kì)

- ze strony Ministerstwa Spraw Wojskowych: M. Nazarenko (M. Nazarenko)

- ze strony Ministerstwa Spraw Wewnętrznych: Stepan Kuzyk (Stepan Kuzik)

- ze strony Ministerstwa Spraw Żydowskich: Jakow Kraiz (Âkov Kraìz)

- ze strony Ministerstwa Pracy: Solomon Goldelman (Solomon Goldelman)

Sekretarzem został Dominik Baszynski (Domìnìk Bašinskiǰ) ${ }^{68}$.

Skład Komisji oraz zespół śledczych zmieniały się wielokrotnie. W pierwszych miesiącach jej działalności liczba członków systematycznie rosła. Na posiedzeniu z 16 lipca Korczynski zaproponował przydzielenie na stałe do Komisji śledczego sądowego S. Kobylkowskiego (S. Kobilkowskiǰ). Tego też dnia członka Komisji ze strony Ministerstwa ds. Żydowskich Kraiza zastąpił Mychajło Alter (Mìhajlo Alter) ${ }^{69}$. Z kolei 18 lipca, znowu w wyniku propozycji Korczynskiego, na stałe przydzielono do składu Komisji śledczego wojskowego chorążego Iwana Watrana (Ivan Vatran) oraz Baszynskiego, pracującego dotychczas jako p.o. sekretarza, datą wsteczną 9 lipca uznanego za jej stałego członka ${ }^{70}$.

${ }^{66}$ ЦДАГОУ, f. 269, ор. 1, sp. 32, „Наказ Директорії Української Народньоі Республіки (По Міністерству Юстиції) ч. 177”, 4 VII 1919, k. 18.

${ }^{67}$ ЦДАГОУ, f. 269, op. 1, sp. 32, List ministra ds. żydowskich do ministra sprawiedliwości, 22 VII 1919, k. 11.

68 ЦДАВОВУ, f. 1123, op. 1, sp. 37, „Засідання 9 VII 1919 р. Особливої Слідчої Комісії по розслідуванню протиєврейських погромних подій”, k. 1. Jakow Kraiz był wcześniej p.o. dyrektora Departamentu Spraw Ogólnych Ministerstwa ds. Żydowskich. $\mathrm{Z}$ zawodu był adwokatem. Decyzję o jego włączeniu do prac Komisji ogłoszono w rozporządzeniu szefa resortu nr 82 z 22 VI 1919 r., ЦДАГОУ, f. 269, op. 1, sp. 32, List ministra ds. żydowskich do ministra sprawiedliwości, 2 VII 1919, k. 16.

${ }^{69}$ ЦДАВОВУ, f. 1123, ор. 1, sp. 37, „Протокол № 4 засідання Особливої Слідчої Комісії по розслідуванню протиєврейських погромних подій 16 VII 1919 р.”, k. 9.

70 ЦДАВОВУ, f. 1123, op. 1, sp. 37, „Протокол № 5 засідання Особливої Слідчої Комісії по розслідуванню протиєврейських погромних подій 18 VII 1919 р.”, k. 10. 
19 lipca, wraz z przekazaniem do rozpatrzenia Komisji szeregu postępowań w sprawie pogromów, a co za tym idzie nagłego wzrostu obciążenia pracą, Korczynski zaproponował przydzielenie do składu sędziego powiatu płoskirowskiego Wołodymyra Donycza (Volodimir Donič), sądowego śledczego I stopnia powiatu głuchowskiego Baszynskiego, członka Sądu Okręgowego Anatolija Łedaszniewa (Anatoliǰ Ledašnêv), sędziego śledczego I stopnia powiatu mohylewskiego Wsewołoda Cebenkę (Vsevolod Cebenko) i sędziego śledczego I stopnia powiatu kuszyckiego W. Wrońskiego (V. Vron'skij̄) ${ }^{71}$. Do śledztwa w sprawie masakry w Płoskirowie wyznaczono członka sądu okręgowego w Kamieńcu Podolskim Ołeksandra Chomenkę (Oleksandr Homenko), do postępowań w sprawie zbrodni w Satanowie i Kupyniu wyznaczono sędziego śledczego powiatu kamienieckiego Ołeksandra Hołuba (Oleksandr Golub). Tymczasem postępowanie w sprawie masakry w Felsztynie powierzono wojskowemu śledczemu sotnykowi Borysowi Sławinskiemu (Boris Slavinskiǰ) ${ }^{72}$.

Mimo systematycznego zwiększania liczby śledczych odznaczających się dużą wiedzą prawniczą, Komisja nieustannie borykała się z deficytem członków. Częste były przypadki odraczania terminu wyjazdu poszczególnych śledczych do miejsc zbrodni. 23 lipca 1919 r. chorąży Watran z powodu choroby nie mógł wyjechać do Kuryłowiec Murowanych i Jaryszowa. Zamiast niego wyznaczono do tego zadania śledczego II stopnia powiatu mohylskiego, niejakiego Ponomariewa (Ponomarêv) ${ }^{73}$. Podobny problem wynikł w przypadku śledczego prowadzącego postępowanie w sprawie najbardziej kontrowersyjnego i głośnego ze wszystkich pogromów, czyli masakry w Płoskirowie. Śledczy Chomenko również nie mógł pojechać na miejsce wydarzeń z powody choroby, dlatego na zastępstwo wyznaczono członka sądu okręgowego Pawła Papmela (Pavlo Papmel). Tymczasem Chomenko został wyłączony z Komisji ${ }^{74}$.

Z powodu bliżej nieustalonych przyczyn do Smotrycza i Makowa nie pojechał Baszynski. W protokole z 13 sierpnia stwierdzono, że „nie radzi sobie" z przekazanymi mu postępowaniami. Podjęto decyzję o tym, że sprawa Smotrycza zostanie przekazana sędziemu Donyczowi, a jeżeli do

${ }^{71}$ ЦДАВОВУ, f. 1123, op. 1, sp. 37, „Протокол № 6 засідання Особливої Слідчої Комісії по розслідуванню протиєврейських погромних подій 19 VII 1919 р.”, k. 1112; С. Єкельчик, op. cit., s. 185.

72 ЦДАВОВУ, f. 1123, op. 1, sp. 37, „Протокол № 12 засідання Особливої Слідчої Комісії по розслідуванню протиєврейських погромних подій 1 VIII 1919 р.”, k. 18.

73 ЦДАВОВУ, f. 1123, op. 1, sp. 37, „Протокол № 8 засідання Особливої Слідчої Комісії по розслідуванню протиєврейських погромних подій 23 VII 1919 р.”, k. 14.

74 ЦДАВОВУ, f. 1123, op. 1, sp. 37, „Протокол № 14 засідання Особливої Слідчої Комісії по розслідуванню протиєврейських погромних подій 6 VIII 1919 р.”, k. 20. 
15 sierpnia Baszynski nie wyjedzie do Makowa, to zostanie tego samego dnia zwolniony z prac w Komisji ${ }^{75}$. Baszynski został wyłączony z prac $\mathrm{z}$ dniem 15 sierpnia, zgodnie $\mathrm{z}$ ostrzeżeniami ${ }^{76}$. W protokole $\mathrm{z} 13$ sierpnia znalazła się również informacja o tym, że również śledczy Sławski (Slavski) nie ma możliwości wyjazdu na miejsce zbrodni. Z kolei śledczy sądu okręgowego w Żytomierzu Turkewycz (Turkevič) uczciwie poinformował, że nie ma możliwości pracy w Komisji śledczej, jego dymisję przyjęto ${ }^{77}$. Na dzień 20 sierpnia żaden śledczy nie prowadził działań w kierunku wyjaśnienia okoliczności zbrodni w Płoskirowie i Felsztynie (niestety nie udało się ustalić, co spowodowało absencję sotnyka Sławinskiego w pracach Komisji). Tego dnia przekazano je kolejno Korczynskiemu i Alterowi ${ }^{78}$. Ponadto po rezygnacji Sławinskiego, który prowadził postępowanie w sprawie zbrodni w Felsztynie, jego miejsce zajął ponownie zatrudniony przez Komisję Baszynski ${ }^{79}$. Na posiedzeniu 15 września Donycz poinformował Komisję, że z uwagi na prowadzenie postępowań w sprawie pogromów w Oryninie, Żwańcu i Makowie nie jest w stanie podjąć się kolejnych zadań ${ }^{80}$.

Przez pierwsze półtora miesiąca działalności Komisja dosyć nieudolnie angażowała śledczych i wyznaczała im postępowania. Doszło do tego, że śledztwa prowadziły osoby $z$ przypadku, łapanki lub przeciążone prowadzonymi postępowaniami (należy pamiętać o tym, że na pogrążonej w chaosie Ukrainie znacznie częstsze były przypadki przestępstw i wykroczeń popełnionych przeciwko nieżydowskim mieszkańcom kraju oraz ich mieniu) ${ }^{81}$. Problem $\mathrm{z}$ deficytem kadr doprowadził do tego, że konieczne stało się angażowanie do prowadzenia postępowań lokalnych

75 ЦДАВОВУ, f. 1123, op. 1, sp. 37, „Протокол № 17 засідання Особливої Слідчої Комісії по розслідуванню протиєврейських погромних подій 13 VIII 1919 р.”, k. 23.

76 ЦДАВОВУ, f. 1123, op. 1, sp. 37, „Протокол № 18 засідання Особливої Слідчої Комісії по розслідуванню протиєврейських погромних подій 15 VIII 1919 р.”, k. 25.

77 ЦДАВОВУ, f. 1123, op. 1, sp. 37, „Протокол № 17 засідання Особливої Слідчої Комісії по розслідуванню протиєврейських погромних подій 13 VIII 1919 р.", k. 23.

78 ЦДАВОВУ, f. 1123, op. 1, sp. 37, „Протокол № 19 засідання Особливої Слідчої Комісії по розслідуванню протиєврейських погромних подій 20 VIII 1919 р.”, k. 26.

${ }^{79}$ ЦДАВОВУ, f. 1123, op. 1, sp. 36, List ministra ds. żydowskich rządu URL do prezesa Nadzwyczajnej Komisji Śledczej ds. Zbadania Antysemickich Pogromów, 2 IX 1919, k. 53; ЦДАВОВУ, f. 1123, op. 1, sp. 37, „Протокол № 21 засідання Особливої Слідчої Комісії по розслідуванню протиєврейських погромних подій 27 VIII 1919 р.”, k. 30.

${ }^{80}$ ЦДАВОВУ, f. 1123, op. 1, sp. 37, „Протокол № 26 засідання Особливої Слідчої Комісії по розслідуванню протиєврейських погромних подій 15 IX 1919 р.”, k. 35.

${ }^{81}$ ЦДАВОВУ, f. 1123 , ор. 1, sp. 36, „Пояснююча записка до додатку до закону про деякі зміни закону від 27-го V 1919 р. Про утрорення Особливоі Слідчоі Комісіі для розслідування протиєврейських погромних подій”, k. 38. 
sędziów i śledczych, którzy nie byli członkami komisji. Mieli oni bezpośrednio prowadzić śledztwa, podczas gdy członkowie Komisji powinni nadzorować ich prace ${ }^{82}$. Sprawę pogromu w Sołobkiwcach przekazano sędziemu Łedaszniewowi, a nadzór sprawował Nazarenko. Z kolei postępowanie w sprawie zbrodni w Szargrodzie przekazano Ponomariewowi, nadzorowanemu przez Solomona Goldelmana ${ }^{83}$.

\section{Wpływ działań wojennych na prace Komisji oraz próby ich sabotowania}

Prowadzenie śledztw zdecydowanie utrudniały działania wojenne. Komisja musiała odroczyć postępowania w sprawie pogromów w Płoskirowie, Felsztynie, Kupyniu i Satanowie z powodu kontrolowania tych miejscowości przez Sowietów ${ }^{84}$. Zdarzało się, że dojazd do miejsc zbrodni był niebezpieczny nawet po wyparciu Armii Czerwonej ${ }^{85}$. Negatywnie na działalności komisji odbiła się również wojna ukraińsko-rosyjska (z siłami SZPR), której ostatecznie Dyrektoriat nie uniknął. Wraz z postępami SZPR zmniejszał się obszar kontrolowany przez URL, a tym samym nikły szanse na skuteczne prowadzenie śledztw ${ }^{86}$.

Wojna wpłynęła negatywnie na możliwość odnalezienia świadków zbrodni. 21 października sędzia Donycz poinformował, że w sprawie zbrodni w Oryninie udało mu się przesłuchać 35 świadków, a uważa za konieczne przesłuchanie jeszcze stu kolejnych ${ }^{87}$. Do 25 października 1919 r. Papmel odnalazł zaledwie 17 świadków pogromu w Płoskirowie. Spośród nich dwóch było Polakami, sześciu Żydami, a reszta Ukraińcami. Śledczy przesłuchał ich w dniach 21, 22 i 24 października. Do kolejnego świadka, szeregowego kozaka armii ukraińskiej, dotarł Monczynski

${ }^{82}$ C. Єкельчик, op. cit., s. 187. Wywołało to niezadowolenie społeczności żydowskiej, ibidem.

${ }^{83}$ ЦДАВОВУ, f. 1123, op. 1, sp. 37, „Протокол № 20 засідання Особливої Слідчої Комісії по розслідуванню протиєврейських погромних подій 22 VIII 1919 р.", k. 27.

${ }^{84}$ ЦДАВОВУ, f. 1123, op. 1, sp. 37, „Протокол № 7 засідання Особливої Слідчої Комісії по розслідуванню протиєврейських погромних подій 21 VII 1919 р.”, k. 13.

85 С. Єкельчик, op. cit., s. 187. Na niedawno wyzwolonych przez Armię URL terenach mogły się błąkać niedobitki lub maruderzy z oddziałów Armii Czerwonej, a także pospolici bandyci.

${ }^{86}$ Na temat wojny ukraińsko-rosyjskiej (SZPR) w 1919-1920, zob. więcej: M. Ковальчук, Невідома війна 1919 року. Украйнсько-білогвардийське збройне протистояння, Київ 2006; idem, Без переможиів. Повстанський рух в Україні проти білогвардийськіх військ генерала А. Денікіна (червень 1919 р. - лютий 1920 р.), Київ 2012.

87 С. Єкельчик, op. cit., s. 188. 
(Mončins'kiǰ). W raporcie nie wyjawiono jednak, czy niewymieniony z nazwiska wojskowy był uczestnikiem czy świadkiem zbrodni. Ponadto wielu świadków pogromu wyjechało z Płoskirowa. W oczach Papmela znacząco utrudniało to dokończenie śledztwa ${ }^{88}$.

Nie można zapominać o kolejnym problemie, z którym przyszło się zmierzyć śledczym Komisji - próbami sabotowania postępowań w terenie przez sprawców zbrodni lub osoby negatywnie nastawione wobec Żydów. Prowadzący postępowanie w sprawie pogromu w Felsztynie, sędzia Monczynski, zetknął się z bezczynnością lokalnej milicji. 8 września 1919 r. wysłał list, w którym zadał pytanie o stan śledztwa w sprawie zbrodni dokonanej na Żydach. Odpowiedź nadeszła dopiero 7 października. Okazało się, że milicjanci nie podjęli żadnych czynności w tej sprawie. Jekelczyk słusznie określił takie zachowanie milicji jako „imitację działalności śledczej”89.

Najbardziej znamiennym przykładem przeciwdziałania pracom Komisji była nieprzyjemna sytuacja, która spotkała sędziego Donycza w Lanckoronie. 11 sierpnia 1919 r. śledczy przybył do tej miejscowości i został zakwaterowany $\mathrm{w}$ jednym $\mathrm{z}$ domów przez starostę. W nocy do jego pokoju wdarło się 10-12 żołnierzy na czele $\mathrm{z}$ oficerem. Mieli na sobie czyste, nieznoszone mundury oraz polskie rogatywki na głowach. Donycz próbował zapobiec przeszukaniu, ukazując swą legitymację, ale jego działania były nieskuteczne. Po godzinie napastnicy zaczęli naradę, która, co było bardzo charakterystyczne, prowadzona była w języku rosyjskim, a nie ukraińskim. Nie odpowiadali na pytania gospodarza. Ukradli jedynie dwie paczki papierosów. Następnego dnia Donycz dowiedział się, że wdarli się też do mieszkania lokalnego naczelnika milicji, ale nie mogacc go znaleźć, zdewastowali kancelarię i udali się do stacji telegraficznej żądając, znowu po rosyjsku, połączenia ze Sztabem Armii Czynnej, podając się za funkcjonariuszy „petlurowskiego wywiadu”. Włamali się również do domu Żyda Mosze Rosenblita, który leżał chory, po czym grozili mu śmiercią, jeżeli nie odda pieniędzy i papierosów. Śledczy dowiedział się od lokalnych mieszkańców, że takie napaści zdarzały się niemal codziennie. Okazało się, że w Lanckoronie od 9 sierpnia naczelnik milicji był nieobecny, a sami milicjanci nie stawiali się w pracy w obawie o swe życie. W obliczu osobistego zagrożenia Donycz zdecydował się na wyjazd $^{90}$. Jego list został odczytany na posiedzeniu Komisji 15 sierpnia

${ }^{88}$ ЦДАВОВУ, f. 1123, op. 1, sp. 1, Raport P. Papmela do Nadzwyczajnej Komisji Śledczej ze śledztwa w sprawie pogromu w Proskurowie, 25 X 1919, k. 8.

${ }^{89}$ С. Єкельчик, op. cit., s. 188.

${ }^{90}$ ЦДАВОВУ, f. 1123, op. 1, sp. 37, Raport sędziego W. Donycza w sprawie zajść w Lanckoronie nr 177, 13 VIII 1919, k. 24. 
1919 r., po czym jej szef zdecydował o konieczności poinformowania Sztabu Armii URL, Ministerstwa Spraw Zagranicznych oraz Ministerstwa ds. Żydowskich o powyższym incydencie ${ }^{91}$.

\section{Postępowania prowadzone przez Nadzwyczajną Komisję Śledczą}

2 lipca 1919 r. Komisja otrzymała, za pośrednictwem ministra sprawiedliwości, dokumentację wszystkich trwających i zakończonych postępowań w sprawie zbrodni na Żydach, które były prowadzone przez Nadzwyczajne Sądy Wojskowe przy Komendancie Zaplecza Armii Czynnej URL. Wszystkie postępowania, nawet ukończone, miały ponownie zostać zbadane przez Nadzwyczajną Komisję Śledczą ${ }^{92}$.

9 lipca I Departament Ministerstwa Sprawiedliwości, będący odpowiednikiem Wydziału Karnego, doprowadził do wydania w ręce Komisji obywatela URL o nazwisku Chomski, który został oskarżony o udział w pogromie w Oryninie 23 maja 1919 r. Zadaniem Komisji była weryfikacja oskarżenia i ponowne przesłuchanie Chomskiego ${ }^{93}$.

19 lipca 1919 r. minister sprawiedliwości wyznaczył Komisji zadanie przeprowadzenia śledztw w sprawie pogromów w: Płoskirowie, Felsztynie, Kuryłowcach Murowanych, Satanowie, Żwańcu, Mińkowcach, Smotryczu, Dunajowcach, Mohylewie Podolskim, Jaryszczowie, Lanckoronie, Zamichowie, Makowie oraz Kupiniu. Jeszcze tego samego dnia przewodniczący poinformował o tej propozycji pozostałych członków instytucji. Została ona jednogłośnie przyjęta. Ponadto Alter zgłosił jeszcze, aby Komisji przekazano również sprawę pogromu w Kitajgrodzie ${ }^{94}$.

${ }^{91}$ ЦДАВОВУ, f. 1123, op. 1, sp. 37, „Протокол № 18 засідання Особливої Слідчої Комісії по розслідуванню протиєврейських погромних подій 15 VIII 1919 р.”, k. 25. Ostatecznie postępowanie w sprawie zbrodni w Lanckoronie kontynuował Mikołaj Łożkin (Mìkola Ložkìn), śledczy wojskowy przy Sztabie Grupy Zaporoskiej Armii Czynnej URL, ЦДАВОВУ, f. 1123, op. 1, sp. 37, „Протокол № 28 засідання Особливої Слідчої Комісії по розслідуванню протиєврейських погромних подій 24-го IX 1919 р.”, k. 37.

${ }^{92}$ ЦДАВОВУ, f. 1123, op. 1, sp. 37, Polecenie Ministra Sprawiedliwości dla Nadzwyczajnej Komisji Śledczej, 2 VII 1919, k. 2.

93 ЦДАВОВУ, f. 1123, op. 1, sp. 37, List Dyrektora I Departamentu Ministerstwa Sprawiedliwości do Nadzwyczajnej Komisji Śledczej, 9 VII 1919 r., k. 3. Interesujące jest to, że 11 lipca Komisja Śledcza stwierdziła, iż Chomski nie był uczestnikiem pogromu w Oryninie i wymagała dalszego ścigania organizatorów i uczestników tej zbrodni, ЦДАВОВУ, f. 1123, op. 1, sp. 37, „Засідання 11 VII 1919 р. Особливої Слідчої Комісії по розслідуванню протиєврейських погромних подій”, k. 5.

${ }^{94}$ ЦДАВОВУ, f. 1123, op. 1, sp. 37, „Протокол № 6 засідання 19 VII 1919 p. Особливої Слідчої Комісії по розслідуванню протиєврейських погромних подій”, 
Równo miesiąc później Ministerstwo Sprawiedliwości po zebraniu (nie bez pomocy ministra ds. żydowskich, o czym niżej), dostatecznej liczby dowodów, wysłało je do Nadzwyczajnej Komisji śledczej z poleceniem wszczęcia kolejnych postępowań. Wysłano: 1) kopię powiadomienia o pogromie w Kamieńcu Podolskim; 2) informację o zamordowaniu Elisza Milgroma i innych; 3) kopię listy zabitych w Kamieńcu Podolskim 3 czerwca 1919 r.; 4) kopię memorandum do ministra ds. żydowskich w sprawie pogromu w Kopajgrodzie; 5) kopię zeznania nt. pogromu w Kopajgrodzie; 6) kopię opisu pogromu w Kopajgrodzie; 7) listę zabitych w Kopajgrodzie podczas pogromu; 8) kopię dokładnego zeznania członków Orynińskiej Żydowskiej Rady Obywatelskiej nt. pogromu w Oryninie; 9) kopię oświadczenia Isera-Kisza Milsteina do Żydowskiej Rady Obywatelskiej miasta Kamieniec Podolski. Nadzwyczajna Komisja Śledcza otrzymała zadanie przeprowadzenia śledztwa w tych miejscowościach ${ }^{95}$. Kilka dni później wysłano Komisji kolejne dowody: 1) kopię prośby upoważnionych z miasta Kopajgród do ministra ds. żydowskich; 2) kopię prośby mieszkańców miasteczka Kopajgród; 3) kopię prośby mieszkańców miasteczka Popowiec i zobligowano Komisję do zbadania tych spraw ${ }^{96}$.

Komisja zajmowała się również przypadkami napaści na pojedyncze osoby, jak np. na obywatela Matusewycza. Niemniej decyzją Komisji ta sprawa została przywrócona do Ministerstwa Sprawiedliwości z uwagi na to, że nie miała związku z pogromami. Ustalono, że pobicia dokonali milicjanci ${ }^{97}$.

W orbicie zainteresowania śledczych znajdowały się również artykuły prasowe nawołujące do pogromów ludności żydowskiej ${ }^{98}$. Minister

k. 11; ЦДАГОУ, f. 269, op. 1, sp. 32, List ministra sprawiedliwości do Nadzwyczajnej Komisji Śledczej, 19 VII 1919, k. 24; С. Єкельчик, op. cit., s. 185.

${ }^{95}$ ЦДАГОУ, f. 269, op. 1, sp. 32, List ministra sprawiedliwości do Nadzwyczajnej Komisji Śledczej, 19 VIII 1919, k. 55.

${ }^{96}$ ЦДАГОУ, f. 269, op. 1, sp. 32, List Ministra Sprawiedliwości do Nadzwyczajnej Komisji Śledczej, w sierpniu 1919, k. 61.

97 ЦДАВОВУ, f. 1123, op. 1, sp. 37, „Протокол № 6 засідання 19 VII 1919 р. Особливої Слідчої Комісії по розслідуванню протиєврейських погромних подій”, k. 12.

98 „Na Nadzwyczajnej Komisji Śledczej spoczywa: a) wszechstronne prowadzenie śledztw [w sprawie] antyżydowskich pogromów na terytorium Ukrainy i zbrodniczej agitacji przeciwko ludności żydowskiej” („На Особливу Слідчу Комісію покладається: a) всестороннє розслідування протиєврейських погромів на територіі Украіни і злочинноі агітаціі проти єврейського населення"), ЦДАВОВУ, f. 1123, ор. 1, sp. 36, „Закон про утворення Особливої Слідчої Комісії для розслідування протиєврейських погромних подій”, 27 V 1919, k. 5; ЦДАГОУ, f. 269, op. 1, sp. 32, „Закон про утворення Особливої Слідчої Комісії для розслідування протиєврейських погромних подій”, 27 V 1919, k. 3; Закон Директорії УНР про утворення Особливої 
ds. żydowskich zwracał bardzo ogólnie uwagę na ten problem w liście do ministra sprawiedliwości z 14 lipca 1919 r.: „cały czas na terytorium Ukrainy szerzy się w wielkim nakładzie drukowana zbrodnicza agitacja przeciwko ludności żydowskiej, która [agitacja] ma charakter zorganizowany"99. 22 września 1919 r. minister ds. żydowskich poprosił ministra sprawiedliwości o wszczęcie przez Nadzwyczajną Komisję śledczą postępowania w sprawie artykułu pt. Jedyne wyjście, który 21 września pojawił się w 34 numerze gazety „Ukraina”. Pikanterii sprawie dodawał fakt, iż wydawcą tego czasopisma była Kwatera Prasowa Sztabu Armii Czynnej ${ }^{100}$. Następnego dnia do Komisji przyszedł list z resortu sprawiedliwości w tej sprawie ${ }^{101}$. 24 września wszczęła ona śledztwo ${ }^{102}$.

Bardzo duży wpływ na to, którymi sprawami zajmie się Nadzwyczajna Komisja Śledcza, miał również minister ds. żydowskich, który jako jeden z pierwszych był informowany o antysemickich zajściach na terytorium URL. Na bieżąco starał się wysyłać w tych sprawach listy do ministra sprawiedliwości z prośbami o to, aby powyższymi przypadkami zajęła się Komisja. Przykładowo w liście z 26 lipca nalegał, aby przekazać jej zadanie zbadania zbrodni w Sołobkiwcach w powiecie uszyckim, do których miało dojść w czerwcu i lipcu 1919 r. ${ }^{103}$ Trzy dni później wysłał do resortu sprawiedliwości kolejny list, tym razem w sprawie zajść we wsi Czemeriwce 21 lipca 1919 r. ${ }^{104} \mathrm{Z}$ kolei 28 sierpnia 1919 r. apelował o rozpoczęcie przez Komisję postępowania w sprawie pogromu w Nowokonstantynówce ${ }^{105}$. Miesiąc

Слідчої Комісії для розслідування єврейських погромів. 27 V 1919, w: В. Сергійчук, Симон Петлюра, s. 100.

99 „Весь час на теріторії України шириться в величезних розмірах рукувана злочинна агитація проти еврейського населення, котра мае в собі всі визнаки цілоі системи", ЦДАГОУ, ф. 269, оп. 1, сп. 32, List ministra ds. żydowskich do ministra sprawiedliwości, 14 VII 1919, k. 21.

${ }^{100}$ ЦДАГОУ, f. 269, op. 1, sp. 32, List ministra ds. żydowskich do ministra sprawiedliwości, 22 IX 1919, k. 82.

101 ЦДАГОУ, f. 269, op. 1, sp. 32, List ministra sprawiedliwości do Nadzwyczajnej Komisji Śledczej, 23 IX 1919, k. 83.

102 ЦДАВОВУ, f. 1123, op. 1, sp. 37, „Протокол № 28 засідання Особливої Слідчої Комісії по розслідуванню протиєврейських погромних подій 24-го IX 1919 р.", k. 37.

103 ЦДАГОУ, f. 269, op. 1, sp. 32, List ministra ds. żydowskich do ministra sprawiedliwości, 26 VII 1919, k. 30. Minister ds. żydowskich dowiedział się od lokalnego starosty i państwowego inspektora Grupy Zaporoskiej Armii Czynnej URL, że w Sołobkiwcach doszło do antysemickich zajść.

104 ЦДАГОУ, f. 269, op. 1, sp. 32, List ministra ds. żydowskich do ministra sprawiedliwości, 29 VII 1919, k. 31.

105 ЦДАГОУ, f. 269, op. 1, sp. 32, List ministra ds. żydowskich do ministra sprawiedliwości, 28 VIII 1919, k. 65. 
później wymagał od Ministerstwa Sprawiedliwości, aby ponagliło komisję w kwestii zakończenia śledztw w sprawie pogromów w Płoskirowie i Felsztynie, które na dobrą sprawę były prowadzone (co prawda z przerwą) od kwietnia 1919 r. ${ }^{106}$ W końcowym okresie prac Nadzwyczajnej Komisji śledczej minister ds. żydowskich przysłał prośbę o wszczęcie śledztwa w sprawie pogromu w Wapniarce, do którego miało dojść 13 maja 1919 r. ${ }^{107}$

Ministerstwo ds. Żydowskich przysyłało również dowody (w postaci zeznań ofiar, świadków, telegramów bądź komunikatów wojskowych lub urzędów cywilnych) do resortu sprawiedliwości, gdzie na ich podstawie decydowano o tym, czy przekazać związane z nimi postępowania do Komisji ${ }^{108}$. Wiele z nich miało dla śledczych bardzo dużą wartość. Przykładowo 2 października 1919 r. powyższy resort przekazał poprzez Ministerstwo Sprawiedliwości kopię zeznań W. Breitmana (V. Breitman), delegata Peczarskiego Komitetu Pomocy Ofiarom Pogromów, i kopię listy zabitych podczas pogromu w Peczarze, w powiecie bracławskim ${ }^{109}$. Problemem okazywał się czasem fakt, iż część dowodów była sporządzana w języku jidysz, co skutecznie utrudniało dalsze postępowanie. $\mathrm{W}$ takim wypadku przygotowywano ukraińskojęzyczne kopie, a oryginały pozostawiano w Ministerstwie ds. Żydowskich. Ministerstwo Sprawiedliwości nie zawsze jednak chciało uznać kopię za wystarczający dowód, co było przyczyną drobnych sporów pomiędzy resortami ${ }^{110}$.

106 ЦДАГОУ, f. 269, op. 1, sp. 32, List ministra ds. żydowskich do ministra sprawiedliwości, 30 IX 1919, k. 85.

107 ЦДАГОУ, f. 269, op. 1, sp. 32, List ministra ds. żydowskich do ministra sprawiedliwości, 28 X 1919, k. 96.

108 Zob. m.in. ЦДАГОУ, f. 269, op. 1, sp. 32, List ministra ds. żydowskich do ministra sprawiedliwości, 5 VIII 1919, k. 33; ЦДАГОУ, f. 269, op. 1, sp. 32, List ministra sprawiedliwości do ministra ds. żydowskich, 8 VIII 1919, k. 34; ЦДАГОУ, f. 269, op. 1, sp. 32, List ministra ds. żydowskich do ministra sprawiedliwości, 15 VIII 1919, k. 52; ЦДАГОУ, f. 269, op. 1, sp. 32, List ministra ds. żydowskich do ministra sprawiedliwości, 19 VIII 1919, k. 54; ЦДАГОУ, f. 269, op. 1, sp. 32, List ministra ds. żydowskich do ministra sprawiedliwości, 28 X 1919, k. 96.

109 ЦДАГОУ, f. 269, op. 1, sp. 32, List ministra ds. żydowskich do ministra sprawiedliwości, 2 X 1919, k. 88.

110 ЦДАГОУ, f. 269, op. 1, sp. 32, List ministra ds. żydowskich do ministra sprawiedliwości, 1 VIII 1919, k. 37; ЦДАГОУ, f. 269, op. 1, sp. 32, List ministra ds. żydowskich do ministra sprawiedliwości, 13 VIII 1919, k. 49; ЦДАГОУ, f. 269, op. 1, sp. 32, List ministra ds. żydowskich do ministra sprawiedliwości, 3 VIII 1919, k. 50; ЦДАГОУ, f. 269, op. 1, sp. 32, List ministra ds. żydowskich do ministra sprawiedliwości, 18 VIII 1919, k. 53. Innym problemem były nieścisłości pojawiające się w dowodach przekazywanych Ministerstwu Sprawiedliwości przez Ministerstwo ds. Żydowskich. Przykładowo 27 sierpnia 1919 r. prezes Nadzwyczajnej Komisji śledczej w liście do szefa pierwszego z resortów zwrócił uwagę na to, że w dokumentach dotyczących pogromu w Kopajgrodzie błędnie 
W ostatnim okresie swej działalności instytucja kierowana przez Mokszynskiego była ponaglana przez ministra sprawiedliwości. Szef tegoż resortu chciał wiedzieć, na jakich etapach znajdują się śledztwa w sprawie pogromów ${ }^{111}$. 3 listopada na posiedzeniu Komisji wysłuchano raportów ze śledztw dotyczących zbrodni w Makowie, Smotryczy, Dunajowcach i Minkowcach ${ }^{112}$. Dwa dni później instytucja ta umorzyła śledztwa w sprawie tych pogromów, poza postępowaniem dotyczącym zbrodni w Minkowcach, z powodu braku dowodów na winę oskarżonych lub nieustalenie sprawców ${ }^{113}$. Dokumenty dotyczące wydarzeń zostały wysłane do sądu w Kamieńcu Podolskim, gdzie 8 listopada 1919 r. miało dojść do rozprawy. Śledztwa w sprawie pozostałych zbrodni (w Jałtuszkowie, Murafie, Mohylewie Podolskim, Jaruzie, Piszczance, Nowokonstantynowie, Kopajgrodzie, Popowcach, Peczarze, Satanowie, Czemerowcach, Kupyniu, Lanckoronie, Janowie, Dżurynie, Zamiechowie, Kuryłowcach Murowanych, Żwańcu, Oryninie, Sołodkowcach, Wapniarce, Felsztynie, Płoskirowie, Kamieńcu Podolskim, Lityniu, Szarogrodzie, Kitajgrodzie, Pohrebyszczach) oraz zachęt w prasie do dokonywania pogromów przekazano sędziom i śledczym wojskowym oraz należacym do sądownictwa powszechnego i administracyjnego ${ }^{114}$.

wskazano powiat uszycki jako miejsce położenia wspomnianego miasta. Tymczasem w tym powiecie mieściło się miasto o bardzo podobnej nazwie - Kitajgród. Tymczasem Kopajgród znajdował się w powiecie mohylowskim. Z tego powodu prezes dociekał, o którą z miejscowości chodziło ministrowi ds. żydowskich. Podobny problem dotyczył błędnego umieszczenia w zeznaniach świadków i wniosku wspomnianego ministra miejscowości Jałtuszków w powiecie uszyckim, podczas gdy leży ona faktycznie w powiecie mohylowskim, ЦДАГОУ, f. 269, op. 1, sp. 32, List szefa Nadzwyczajnej Komisji Śledczej do ministra sprawiedliwości w kwestii nieścisłości dotyczących postępowania w sprawie pogromu w Kopajgrodzie, 27 VIII 1919, k. 63; ЦДАГОУ, f. 269, op. 1, sp. 32, List szefa Nadzwyczajnej Komisji Śledczej do ministra sprawiedliwości w kwestii nieścisłości dotyczących postępowania w sprawie pogromu w Jałtuszkowie, 27 VIII 1919, k. 64. Tego samego dnia minister sprawiedliwości uściślił, iż dowody dotyczyły Kitajgrodu i Jałtuszkowa w powiecie uczyckim, ЦДАГОУ, f. 269, op. 1, sp. 32, Odpowiedź Ministerstwa Sprawiedliwości na list prezesa Nadzwyczajnej Komisji Śledczej, 27 VIII 1919, k. 68-69.

${ }^{111}$ ЦДАГОУ, f. 269, op. 1, sp. 32, List ministra sprawiedliwości do Nadzwyczajnej Komisji Śledczej, 24 X 1919, k. 93.

112 ЦДАВОВУ, f. 1123, op. 1, sp. 37, „Протокол № [brak nr.] засідання Особливої Слідчої Комісії по розслідуванню протиєврейських погромних подій 3-го ХІ 1919 р.", k. 47.

${ }^{113}$ ЦДАВОВУ, f. 1123, op. 1, sp. 37, „Протокол № [brak nr.] засідання Особливої Слідчої Комісії по розслідуванню протиєврейських погромних подій 8 XI 1919 р.", k. 48.

114 ЦДАГОУ, f. 269, op. 1, sp. 32, Sprawozdanie Nadzwyczajnej Komisji Śledczej z aktualnego stanu prowadzonych postępowań, 5 XI 1919, k. 98-99; С. Єкельчик, op. cit., s. 189. 


\section{Polityka finansowa Nadzwyczajnej Komisji Śledczej}

Środki finansowe dla Komisji miały pochodzić ze skarbu państwa i być jej przekazywane za pośrednictwem Ministerstwa Sprawiedliwości. Członkowie Komisji, poza pensją ze swych stałych posad oraz dodatkami, mieli otrzymywać również po 50 hrywien dniówki, podczas gdy pracownicy kancelarii po 30 hrywien. Tymczasem członkowie Komisji niemający pracy poza nią mieli otrzymywać: prezes 150 hrywien, członkowie po 120 hrywien, sekretarz kancelarii 100 hrywien, a pracownicy kancelarii po 80 hrywien dziennie. Terminem otrzymania wypłaty był koniec tygodnia. Fundusze w wysokości 200 tys. hrywien, przeznaczone na utworzenie Komisji, miały być wyasygnowane rozporządzeniem ministra sprawiedliwości ${ }^{115}$.

Zaraz po przyjęciu ustawy zaproponowano do niej liczne poprawki i uzupełnienia. Uwzględniały one okoliczności, w jakich miało przyjść funkcjonować tej instytucji. Bardzo ważne było uzupełnienie do art. 10. W przypadku braku śledczych wojskowych i sądownictwa powszechnego dawało ono komisji prawo do przyjmowania na stanowiska śledczych osób z wykształceniem wyższym, które nie zajmowały posad wymienionych w tym fragmencie ustawy, ale na innych stanowiskach nabyły doświadczenie w zakresie prowadzenia śledztw ${ }^{116}$.

115 ЦДАВОВУ, f. 1123, op. 1, sp. 36, „Закон про утворення Особливої Слідчої Комісії для розслідування протиєврейських погромних подій”, 27 V 1919, k. 6; ЦДАГОУ, f. 269, ор. 1, sp. 32. „Закон про утворення Особливої Слідчої Комісії для розслідування протиєврейських погромних подій”, 27 V 1919, k. 3; Закон Директорії УНР про утворення Особливої Слідчої Комісії для розслідування єврейських погромів. 27 V 1919, w: В. Сергійчук, Симон Петлюра, s. 102-103; С. Єкельчик, op. cit., s. 185. Dla porównania, wiosną 1919 r. dowódcy dywizji i naczelnicy wydziałów Sztabu Generalnego Armii URL otrzymywali żołd miesięczny w wysokości 2800 hrywien, dowódcy pułków po 2400, dowódcy sotni po 1600, a szeregowi kozacy po 600 hrywien (por. ЦДАВОВУ, f. 3172, op. 5, sp. 2, „Наказ Військам Дієвої Армії Української Народної Республіки ч. 26”, 20 III 1919, k. 25), dowódca (pieszej) sotni rozpoznania przy Sztabie Armii URL 1800 hrywien, a dowódca czoty w tejże sotni 1500 hrywien (por. ЦДАВОВУ, f. 3172, op. 5, sp. 2, „Наказ Військам Дієвої Армії Української Народної Республіки ч. 60", 3 IV 1919, k. 50).

116 ЦДАВОВУ, f. 1123, op. 1, sp. 36, „Додаток до закону від 27-го V 1919 р. Про утрорення Особливоі Слідчоі Комісіі для розслідування протиєврейських погромних подій”, k. 36; ЦДАВОВУ, f. 1123, op. 1, sp. 36, „Пояснююча записка до додатку до закону про деякі зміни закону від 27-го V 1919 р. Про утрорення Особливоі Слідчоі Комісіі для розслідування протиєврейських погромних подій”, k. 39; ЦДАВОВУ, f. 1123, op. 1, sp. 36, „Ухвалена Радою Народних Міністрів постанова про де-які зміни закону від 27-го V 1919 р. про утворення Особливої Слідчої Комісії для розслідування протиєврейських погромних подій”, 9 VII 1919, k. 40. 
W kolejnej nowelizacji podwyższono uposażenie członkom Komisji. Płace dzienne osób posiadających zatrudnienie poza Komisją zwiększono z 50 do 100 hrywien, a nieposiadających stałych posad do 240 hrywien. Przewodniczący miał otrzymywać 300 hrywien. Osoby wyznaczone przez Komisję do przeprowadzenia postępowania w terenie otrzymać miały dodatkowe 100 hrywien na dobę. Płace pracowników kancelarii również zwiększono - z 30 do 60 hrywien. Ponadto, ci kancelarzyści, którzy nie posiadali innego zatrudnienia, mieli otrzymywać po 160 hrywien dziennie, a sekretarz 200 hrywien. Zmiany w pensjach były spowodowane rosnącymi cenami artykułów żywnościowych i potrzebami członków Komisji oraz osób wykonujących jej zlecenia ${ }^{117}$.

Poważnym wyzwaniem, przed którym stanęła Komisja, był niedobór zasobów finansowych. Fundusze były potrzebne na wypłaty dla śledczych i innych urzędników tej instytucji. Prowadzący postępowania musieli ponadto dysponować środkami na dojazd na miejsce zbrodni, zakwaterowanie i wyżywienie. Można śmiało podejrzewać, że część pieniędzy była przeznaczana na łapówki, mające przekonać świadków do złożenia zeznań. Ponadto potrzebne były maszyna do pisania, papier i inne artykuły biurowe. Dopiero 16 lipca na wyposażeniu Komisji znalazła się maszyna do pisania118, co było zapewne spowodowane priorytetowym zaopatrywaniem w sprzęt biurowy najważniejszych ministerstw, instytucji wojskowych oraz administracji URL, na co zresztą wskazuje bardzo duża liczba drukowanych materiałów archiwalnych.

Nie lepiej wyglądała sytuacja $\mathrm{z}$ funduszami przewidzianymi na wypłaty dla śledczych i ich wyjazdy na miejsca zbrodni. Dodatkowo niekorzystnie na prowadzenie przez nich długich postępowań w terenie wpływała drożyzna żywności. Znalazło to swój wydźwięk w wystąpieniu przedstawiciela Ministerstwa Sprawiedliwości Zawadskiego na posiedzeniu komisji 4 sierpnia 1919 r. Śledczy dostawali jedynie 25 karbowańców dziennie, co było sumą niewystarczającą. Niskie płace demotywowały część członków Komisji. W związku z tym kierownictwo tej instytucji

117 ЦДАВОВУ, f. 1123, ор. 1, sp. 36, „Закон про деякі зміни закону від 27-го V 1919 р. Про утрорення Особливоі Слідчоі Комісіі для розслідування протиєврейських погромних подій”, k. 37; ЦДАВОВУ, f. 1123, op. 1, sp. 36, „Пояснююча записка до закону про деякі зміни закону від 27-го V 1919 р. Про утворення Особливоі Слідчоі Комісіі для розслідування протиєврейських погромних подій”, k. 38; ЦДАВОВУ, f. 1123, op. 1, sp. 36, „Ухвалена Радою Народних Міністрів постанова про деякі зміни закону від 27-го V 1919 р. про утворення Особливої Слідчої Комісії для розслідування протиєврейських погромних подій”, 9 VII 1919, k. 40.

118 ЦДАВОВУ, f. 1123, op. 1, sp. 37, „Протокол № 4 засідання Особливої Слідчої Комісії по розслідуванню протиєврейських погромних подій 16 VII 1919 р.", k. 9. 
zdecydowało się wystosować prośbę o wyasygnowanie z budżetu państwa dodatkowych funduszy ${ }^{119}$. Tydzień później Zawadski zaproponował podwyższenie dniówki śledczym, ale do korzystnych zmian ostatecznie nie doszło ${ }^{120}$.

6 września przekazano do Ministerstwa Sprawiedliwości prośbę o wyasygnowanie $1 \mathrm{mln}$ hrywien na rzecz Komisji. Prawdopodobnie z powodu intensywnych działań wojennych Dyrektoriat nie traktował tej kwestii jako priorytetowej. Dlatego też niecały miesiąc później Zawadski nalegał, aby podjąć usilne starania na rzecz wydzielenia dla Komisji połowy z wcześniej postulowanej sumy, choć nadal miano nadzieję, że reszta zostanie przekazana później, w drugiej transzy. Wpływ na zmianę postulatu miał fakt, że prośba o wyasygnowanie $1 \mathrm{mln}$ hrywien nie została jeszcze rozpatrzona przez Komisję Budżetu ${ }^{121}$.

Na posiedzeniu 3 października 1919 r. poinformowano członków Nadzwyczajnej Komisji Śledczej, że posiada ona do swej dyspozycji jedynie 3 tys. hrywien wolnych środków. Reszta pieniędzy była przewidziana na inne wydatki. Śledczy przydzieleni do prac nie otrzymywali wypłaty od 20 września, a stawki w wysokości 25 karbowańców dniówki utrzymały się. Na domiar złego w projekcie kolejnej ustawy budżetowej rządu URL skorygowano wysokość środków przeznaczonych na jej działalność z 1 mln do 500 tys. hrywien. To była maksymalna suma, na którą mogła liczyć ta instytucja ${ }^{122}$. Szczegóły wydatków Komisji zawiera sprawozdanie finansowe złożone 3 października do II Departamentu Ministerstwa Sprawiedliwości. Z 200 tys. hrywien Komisja wykorzystała 171 329,50 do 1 października, zatem instytucji pozostało jeszcze 28670 hrywien i 50 kopiejek. Z tej sumy znaczną część stanowiły jednak również niepokwitowane środki przekazane śledczym i pracownikom kancelarii w wysokości 15 980,50 hrywien ${ }^{123}$.

Do końca swej działalności Komisja stykała się z niedostatkiem funduszy. Jak wynika z wyciągu z Dziennika Posiedzeń Rządu URL

119 ЦДАВОВУ, f. 1123, op. 1, sp. 37, „Протокол № 13 засідання Особливої Слідчої Комісії по розслідуванню протиєврейських погромних подій 4 VIII 1919 р.”, k. 19.

120 ЦДАВОВУ, f. 1123, op. 1, sp. 37, „Протокол № 16 засідання Особливої Слідчої Комісії по розслідуванню протиєврейських погромних подій 11 VIII 1919 р.”, k. 22.

121 ЦДАВОВУ, f. 1123, op. 1, sp. 37, „Протокол № [brak nr.] засідання Особливої Слідчої Комісії по розслідуванню протиєврейських погромних подій 3-го Х 1919 p.", k. 42.

122 Ibidem; ЦДАГОУ, f. 269, op. 1, sp. 32, Sprawozdanie Nadzwyczajnej Komisji śledczej z aktualnego stanu prowadzonych postępowań, 5 XI 1919, k. 98.

123 ЦДАГОУ, f. 269, op. 1, sp. 32, Sprawozdanie finansowe Nadzwyczajnej Komisji Śledczej, 3 X 1919, k. 86. 
z 20 października 1919 r., minister sprawiedliwości starał się o wyasygnowanie 500 tys. hrywien na jej działalność, z czego ostatecznie otrzymano zaledwie 200 tys. ${ }^{124}$

\section{Działalność ukraińskiej Nadzwyczajnej Komisji Śledczej na tle podobnych instytucji w innych państwach}

Jedynym państwem Europy Środkowo-Wschodniej, które, poza URL, powołało do życia komisję śledczą mającą zbadać problem pogromów, była Polska. Stworzono ją, aby przeprowadzić śledztwo w sprawie zajść we Lwowie w dniach 22-24 listopada 1918 r. Parę godzin po odwrocie wojsk ukraińskich z miasta ${ }^{125}$ kilka polskich oddziałów wojskowych rozpoczęło plądrowanie dzielnicy żydowskiej. Do żołnierzy szybko przyłączył się tłum polskich mieszkańców Lwowa. Świadkowie zauważyli wśród sprawców pogromu przedstawicieli wszystkich sfer społecznych: elit intelektualnych, rzemieślników, robotników, biedoty miejskiej. W wyniku dwóch dób plądrowania życie straciło kilkadziesiąt osób, straty materialne były ogromne. Wieści o pogromie lwowskim bardzo szybko zaczęły żyć własnym życiem - w zagranicznej prasie zawyżano liczbę ofiar ${ }^{126}$.

Zajścia we Lwowie, zwłaszcza w połączeniu z informacjami o podobnych wydarzeniach z innych części kraju, poważnie nadszarpnęły wizerunek młodego państwa w oczach Ententy. W opinii Zachodu pogromy były oznaką tego, że rząd w Warszawie nie kontroluje własnych sił zbrojnych oraz nie jest w stanie zapewnić stabilizacji wewnątrz państwa. Z tego powodu 30 listopada 1918 r. Rada Ministrów wydała oświadczenie potępiające pogrom i w grudniu powołała do życia komisję śledczą, na czele której stanął sędzia Zygmunt Rymowicz, znany i szanowany prawnik.

124 ЦДАВОВУ, f. 1123, op. 1, sp. 36, Wyciąg z Dziennika posiedzeń Rady Ludowych Ministrów nr 217, 20 X 1919, k. 55. Serhij Jekelczyk błędnie stwierdza, że Komisja otrzymała całą sumę, por.: С. Єкельчик, op. cit., s. 188.

125 Więcej informacji nt. walk miejskich o Lwów w dniach 1-22 XI 1918 r., m.in.: A. Próchnik, Obrona Lwowa, Zamość 1919, passim; О. Кузьма, Листопадові дні 1918 p., Львів 1931, passim; M. Kozłowski, Zapomniana wojna. Walki o Lwów i Galicję Wschodnią 1918-1919, Bydgoszcz 1999, s. 145-212; М. Литвин, op. cit., s. 38-106; M. Klimecki, op. cit., s. 53-135.

${ }^{126}$ Problem pogromu we Lwowie opisano obszernie w następujących opracowaniach: L. Kania, W cieniu Orlą Lwowskich. Polskie sądy wojskowe, kontrwywiad i służby policyjne w bitwie o Lwów 1918-1919, Zielona Góra 2008, s. 95-101; G. Gauden, Lwów - kres iluzji. Opowieść o pogromie listopadowym 1918, Kraków 2019, passim. 


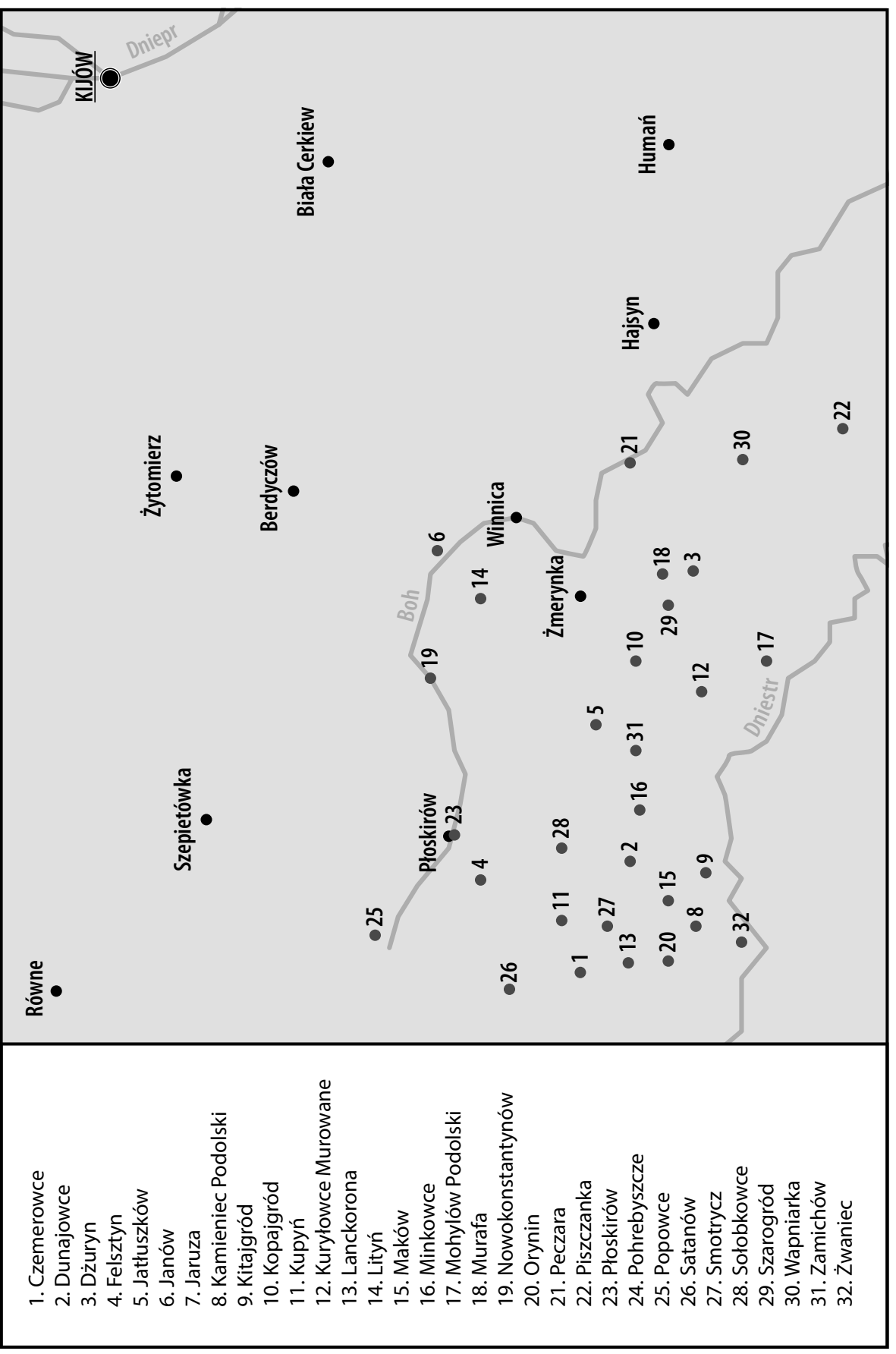


Po kilku tygodniach działania komisja opublikowała raport dotyczący pogromu. Sędzia stwierdził, że lokalne dowództwo okazało się nieudolne w zaprowadzaniu dyscypliny w swych szeregach, a wysyłane do dzielnicy żydowskiej patrole przyłączały się do łupieżców. Zdaniem Rymowicza życie straciło ok. 50 osób, a straty materialne wyniosły 35-40 mln koron austriackich. Polskiemu prawnikowi udało się również ustalić personalia niektórych sprawców ${ }^{127}$.

Brak informacji na temat tworzenia analogicznych instytucji przez rząd Południa Rosji. Formacje poporządkowane gen. Antonowi Denikinowi (Anton Denikin) znane były z dokonania dużej liczby masakr, które charakteryzowały się niespotykanym okrucieństwem sprawców. Co ciekawe, zbrodnie „białych” nie wywoływały większego wrażenia na rządach państw Ententy. W ich oczach Denikin uchodził za przywódcę, który miał największe szanse na pokonanie Sowietów i odbudowanie Imperium Rosyjskiego, jako sojusznika państw zwycięzców I wojny światowej. Z tego powodu ignorowano wyczyny wielu „białych” formacji, a do SZPR nieustanie napływały broń, amunicja i inne materiały niezbędne do prowadzenia działań wojennych ${ }^{128}$.

Bolszewicy również nie stworzyli komisji do zbadania pogromów dokonanych przez Armię Czerwoną. Choć dziś uważa się, że liczba tego typu przestępstw „czerwonych” była nieco wyższa ${ }^{129}$, jednak nie wpływa to na ogólny obraz, w którym krasnoarmiejcy rzadziej mordowali i terroryzowali Żydów niż pozostałe siły wojujące na Ukrainie w latach 1918-1920.

\section{Ocena prac Nadzwyczajnej Komisji Śledczej}

W oparciu o dostępny materiał źródłowy można stwierdzić, że Dyrektoriat i rząd ukraiński kierowały się szczerą chęcią zbadania zbrodni i zapobiegnięcia kolejnym przestępstwom. Stały za tym nie tyle idealizm i sympatia socjalistów ukraińskich wobec Żydów, ale kwestie bardzo praktyczne. Sprawcy pogromów byli od samego początku jednym z czołowych źródeł

127 Szerzej: L. Kania, op. cit., s. 136-160.

128 Na temat stosunku Rządu Południa Rosji oraz SZPR do Żydów, zob. А. Пученков, Национальная политика генерала Деникина (весна 1918 - весна 1920), Санкт-Петербург 2012, s. 201-272.

129 О. Будницкий, op. cit., s. 216-217. Dla porównania, warto dodać, że w raporcie kijowskiego oddziału rosyjskiego Czerwonego Krzyża stwierdzono, iż żołnierze Armii Czerwonej odpowiadali za wymordowanie ok. 500 ukraińskich Żydów w 1919 r., Report of pogroms in the Ukraine. By the Kiev Pogrom Relief Committe of the Russian Red Cross, w: The Ukraine terror and the Jewish peril, London 1921, s. 11. 
anarchii i demoralizacji społeczeństwa oraz armii. Ich wyczyny ograniczały możliwości ukraińskich sił zbrojnych, gdyż władze URL musiały odsyłać z frontu bitne i zdyscyplinowane oddziały, aby zaprowadzały porządek na tyłach lub zapobiegały kolejnym antysemickim ekscesom. Ponadto prowodyrami wielu pogromów byli atamanowie, którzy zabierali swe oddziały ze strefy działań bojowych tam, gdzie mogli bezkarnie dokonywać przestępstw na Żydach. Niemal zawsze sprawcy tych zbrodni grabili również ludność ukraińską oraz instytucje państwowe ${ }^{130}$. Można podejrzewać, że Petlura i zwolennicy formowania regularnej armii ukraińskiej zamierzali wykorzystać prace komisji śledczych, a następnie sądy do rozprawienia się z niezdyscyplinowanymi watażkami. Większość z nich nie była poza tym związana politycznie z Petlurąa ${ }^{131}$. Pozbywając się ich, główny ataman stopniowo zwiększał swoje wpływy we władzach centralnych URL, a także pokonywał kolejne przeszkody w drodze do sformowania regularnych sił zbrojnych. Niezbędne jednak będą dalsze badania archiwalne, które pozwolą na potwierdzenie lub odrzucenie powyższej tezy.

Z powodu wielu niesprzyjających okoliczności, braku środków oraz niskich kompetencji części członków Nadzwyczajnej Komisji Śledczej nie udało się doprowadzić do skazania w drugiej połowie 1919 r. czołowych prowodyrów pogromów. Krytyczne uwagi względem Komisji miał minister ds. żydowskich, który pod koniec października 1919 r. oskarżał śledczych o nieudolność. W ramach odpowiedzi na jednym z ostatnich posiedzeń tej instytucji zwrócono uwagę Pinchasowi Krasnemu, że w swych zarzutach nie zawarł konkretów. Poproszono go przy tym o propozycje kadrowe, które miałyby wpłynąć na poprawę prac Komisji ${ }^{132}$. Prośba członków instytucji pozostała bez odpowiedzi.

Pomimo tego, że prace Komisji nie przyczyniły się bezpośrednio do ukarania kogokolwiek ze sprawców i organizatorów pogromów ${ }^{133}$,

130 M.in. ЦДАГОУ, f. 269, op. 1, sp. 36, Kopia telegramu komendanta powiatu izjasławskiego Biłokonia do dowódcy Północno-Zachodniej Grupy Wojsk URL atamana W. Oskiłki, 8 II 1919, k. 80; ЦДАГОУ, f. 269, op. 1, sp. 37, Protokół przeszukania atamana Josyfa Bidenki, 26 II 1919, k. 12; С. Єкельчик, op. cit., s. 191; Ю. Мітрофаненко, op. cit., s. 81-99.

${ }^{131} \mathrm{Na}$ protekcję jednego z członków Dyrektoriatu, Panasa Andrijewskiego, mógł liczyć ataman Josyf Bidenko (josif Bìdenko). Bardzo luźno związani z jego partią byli Iwan Semensenko i Kozyr-Zirka (Oleksandr Kozir-Zìrka), G. Skrukwa, op. cit., s. 408; Ю. Мітрофаненко, ор. cit., s. 71.

132 ЦДАВОВУ, f. 1123, op. 1, sp. 37, „Протокол № [brak nr.] засідання Особливої Слідчої Комісії по розслідуванню протиєврейських погромних подій 22-го Х 1919 p.", k. 45.

${ }^{133}$ С. Єкельчик, op. cit., s. 189. 
to jednak umożliwiły zebranie wielu ważnych dowodów, głównie w postaci zeznań świadków. Pozwalają one współczesnym historykom na wnikliwe i nieobarczone stereotypami spojrzenie na problem zbrodni antysemickich na Ukrainie oraz stosunku Dyrektoriatu URL do tych tragicznych wydarzeń. Stanowią ponadto interesujące źródło informacji na temat problemów kadrowych, finansowych oraz polityczno-militarnych, z którymi musiały borykać się władze ukraińskie w 1919 r.

\section{Streszczenie}

Autor opisał niemal nieznany temat działalności Nadzwyczajnej Komisji Śledczej ds. Zbadania Antysemickich Pogromów na terytorium Ukraińskiej Republiki Ludowej. Jej działalność obejmowała okres od lipca do listopada 1919 r., a celem było ustalenie przebiegu i personaliów sprawców pogromów oraz pociągnięcie zbrodniarzy do odpowiedzialności karnej. Po odbudowie URL nowe władze ukraińskie musiały stawić czoło agresji zewnętrznej oraz licznym problemom wewnętrznym. Jednym z najpoważniejszych były pogromy ludności żydowskiej dokonywane głównie przez nieregularne formacje Armii URL. Dyrektoriat i rząd republiki podjęły szereg działań mających na celu ukaranie sprawców zbrodni oraz powstrzymanie kolejnych ataków na ukraińskich Żydów. Utworzenie Nadzwyczajnej Komisji śledczej stanowi interesujący przykład reakcji ukraińskich władz na zbrodnie dokonywane na żydowskiej ludności nad Dnieprem w 1919 r.

\section{Activities of the Special Commission to Investigate Anti-Jewish Pogroms in the Territory of the Ukrainian People's Republic in 1919}

In his article, the author describes an almost unknown aspect of the activities of the Special Commission to Investigate Anti-Jewish Pogroms in the Territory of the Ukrainian People's Republic. It operated from July to November 1919 in order to establish the course and personal data of the pogroms' perpetrators and to bring the criminals to justice. After the re-establishment of the Ukrainian People's Republic, the new Ukrainian authorities had to face both aggression from outside and numerous internal problems. One of the most serious were pogroms against the Jewish population, organised and conducted by irregular formations of the Army of the UPR. The directorate and the government of the republic took a range of measures to punish the crimes' perpetrators and stop further attacks on Ukrainian Jews. The establishment of the Special Investigation Commission is an interesting example of the reaction of the Ukrainian authorities to the crimes committed against the Jewish population in the Dnieper valley in 1919. 


\section{Bibliografia}

Anti-Jewish Violence. Rethinking the Pogrom in East European History, red. Jonathan Dekel-Chen, David Gaunt, Natan M. Meir, Israel Bartal, Indiana University Press, Bloomington 2010.

Bruski Jan Jacek, Petlurowcy. Centrum Państwowe Ukraińskiej Republiki Ludowej na wychodźstwie (1919-1924), Arcana, Kraków 2000.

Budnitskii Oleg, Russian Jews between Whites and Reds 1917-1920, University of Pennsylvania Press, Philadelphia 2012.

Friedman Saul S., Pogromchik. The Assassination of Simon Petlura, Hart Publishing Company, New York 1976.

Gauden Grzegorz, Lwów - kres iluzji. Opowieść o pogromie listopadowym 1918, Universitas, Kraków 2019.

Heifetz Elias, The Slaughter of the Jews in the Ukraine in 1919, Thomas Seltzer, New York 1921.

Hunczak Taras, Symon Petliura and the Jews. A Reappraisal, Ukrainian Historical Association, Lviv-New York-Toronto 2008.

Kania Leszek, W cieniu Orląt Lwowskich. Polskie sądy wojskowe, kontrwywiad i służby policyjne w bitwie o Lwów 1918-1919, Uniwersytet Zielonogórski, Zielona Góra 2008.

Klimecki Michał, Lwów 1918-1919, Bellona, Warszawa 1998.

Kowalczyk Andrzej, Pan Petlura?, Open, Warszawa 1998.

Kozłowski Maciej, Zapomniana wojna. Walki o Lwów i Galicję Wschodnia 1918-1919, Świadectwo, Bydgoszcz 1999.

Kozubel Marek Bogdan, O relacjach między sądownictwem Państwa Ukraińskiego a sądami wojskowymi armii Państw Centralnych na Ukrainie w 1918 roku, w: Pogranicza $w$ historii prawa i myśli polityczno-prawnej, red. Przemysław Dąbrowski, Dariusz Szpoper, Uniwersytet Warmińsko-Mazurski w Olsztynie, Gdańsk-Olsztyn 2017, s. 355-368.

Kozubel Marek Bogdan, Przestępczość w Państwie Ukraińskim w okresie koniec lipca sierpień 1918 r. - analiza na podstawie wybranych materiałów Centralnego Państwowego Archiwum Wyższych Organów Władzy i Administracji Ukrainy w Kijowie, „Studia z Dziejów Rosji i Europy Środkowo-Wschodniej” 54, 2019, 2, s. 109-128.

Krotofil Maciej, Siły Zbrojne Ukraińskiej Republiki Ludowej (listopad 1918 r. - grudzień 1919 r.), Stylos, Kijów 2011.

Krotofil Maciej, Ukraińska Armia Halicka 1918-1920. Organizacja, uzbrojenie, wyposażenie i wartość bojowa sił zbrojnych Zachodnio-Ukraińskiej Republiki Ludowej, Wydawnictwo Adam Marszałek, Torun 2002.

Legieć Jacek, Armia Ukraińskiej Republiki Ludowej w wojnie polsko-ukraińsko-bolszewickiej w 1920 r., Wydawnictwo Adam Marszałek, Toruń 2002.

Liber George, Wojny totalne i kształtowanie się współczesnej Ukrainy 1914-1954, Księgarnia Akademicka, Kraków 2019.

Mędrzecki Włodzimierz, Niemiecka interwencja militarna na Ukrainie w 1918 roku, DiG, Warszawa 2000.

Midlarsky Manus, The Killing Trap. Genocide in the Twentieth Century, Cambridge University Press, Cambridge 2005. 
Próchnik Adam, Obrona Lwowa, Zygmunt Pomarański i spółka, Zamość 1919.

Report of pogroms in the Ukraine. By the Kiev Pogrom Relief Committe of the Russian Red

Cross, w: The Ukraine terror and the Jewish peril, the Federation of Ukrainian Jews, London 1921.

Skrukwa Grzegorz, Formacje wojskowe ukraińskiej „rewolucji narodowej” 1914-1921, Wydawnictwo Adam Marszałek, Torun 2008.

Szajdak Sebastian, Polsko ukraiński sojusz polityczno-wojskowy w 1920 roku, Oficyna Wydawnicza Rytm, Warszawa 2005.

Абинякин Роман, Офицерский корпус Добровольческой Армии. Соц̧ильный состав, мировоззрение. 1917-1920 г2., Издатель А. Воробьев, Орел 2005.

Абрамсон Генрі, Молитва за владу. Українизі та євреї під час революизї (1917-1920), Дух і Літера, Київ 2017.

Будницкий Олег, Российские Евреи между Красными и Белыми (1917-1920), РОСПЄН, Москва 2005.

Вооруженные силы на Юге Росии, январь - июнь 1919 года, red. Сергей Волков, Центрполиграф, Москва 2003.

Гольдельман Соломон, Жидівська національна автономія на Україні (1917-1920 рр.), Іститут для вивчення СССР, Мюнхен 1963.

Гражкданская Война на Украине 1918-1920. Сборник документов і материалов в трех томах, четырех книгах, t. 1, cz. 1, red. Степан Короливский, Николай Колесник, Иван Рыбалка, Издательство „Наукова Думка”, Киев 1967.

Дєдик Олександр, Чортківська офензива, cz. 1 і 2, Астролабія, Львів 2015.

Директорія, Рада Народних Міністрів Української Народної Республіки 1918-1920. Документи і матеріали у 2 томах, t. 1-2, орrac. Владислав Верстюк, Видавництво ім. Олени Теліги, Київ 2006.

Дорошенко Дмитро, Історія України 1917-1923 рр., t. 2: Українська Гетьманська Держава 1918 р., Темпора, Київ 2002.

Єкельчик Сергій, Трагічна сторінка Української революциї. Симон Петлюра та єврейські погроми в Україні (1917-1920), w: Симон Петлюра та українська національна революиія. Збірник прац̧ь другого конкурсу петлюрознавцзів України, red. Василь Михальчук, Рада, Київ 1995.

Капустянський Микола, Похід українських армій на Київ-Одессу в 1919 році, w: Україна. 1919 рік. М. Капустянський „Похід українських армій на Київ-Одессу в 1919 роизі. Є. Маланюк „Уривки зі спогадів”. Документи та матеріали, red. Ярослав Тинченко, Темпора, Київ 2004.

Кенез Питер, Подлинная история Добровольческой армии 1917-1918, ТД Алгоритм, Москва 2017.

Ковальчук Михайло, Без переможиів. Повстанський рух в Україні проти білогвардийськіх військ генерала А. Денікіна (червень 1919 р. - лютий 1920 р.), Стилос, Київ 2012.

Ковальчук Михайло, Невідома війна 1919 року. Українсько-білогвардийське збройне протистояння, Темпора, Київ 2006.

Крипякевич Іван, Гнатєвич Богдан, Стефанів Зенон, Думін Осип, Шрамченко Святослав, Історія українського війська, Видання Івана Тиктора, Львів 1936. Кузьма Олекса, Листопадові дні 1918 р., наклад автора, Львів 1931. 
Литвин Микола, Українсько-польська війна 1918-1919 рр., НАН України, Львів 1998. Макарчук Степан, Українська Республіка Галичан, Світ, Львів 1997.

Мітрофаненко Юрій, Українська отаманщзина 1918-1919 років, wуd. 3, Імекс-ЛТД, Кропивницький 2016.

Папакін Георгій, Павло Скоропадський. Патріот, державотворец̧ь, людина. Iсторико-архівні нариси, Державний комітет архівів України, Центральний державний історичний архів України, Київ 2003.

Пінак Євген, Чмир Микола, Військо Української революиіï 1917-1921 років, Книжковий Клуб „Клуб Сімейного Дозвілля”, Харків 2017.

Пиріг Руслан, Осташко Тетяна, Гетьманська Держава, w: Нариси історії Української Революиіï 1917-1921 років, t. 1, red. Валерій Смолій, НВП Видавництво „Наукова думка”, НАН України, Київ 2011, s. 348-371.

Пиріг Руслан, Українська гетьманська держава 1918 року. Історичні нариси, НАН України, Київ 2011.

Проскурівський погром 1919 року в документах: міфи та реальність, оргас. Володимир Сергійчук, Олександр Завалюк, Володимир Байдич, Юрій Олійник, Віталій Галатир, ТОВ „Твори”, Хмельницький 2019.

Пученков Александр, Национальная политика генерала Деникина (весна 1918 весна 1920), Полторак, Санкт-Петербург 2012.

Резніков Володимир, Антигетьманський повстанський рух на Слобожанщині (травень-листопад 1918 року), „Молодий вчений”, май 2015, 5 (20), сz. 1, s. $77-83$.

Резніков Володимир, Селянський повстанський рух на Слобожанщзині (березень 1918-1923 рр.), w: Війна з держкавою чи за держкаву? Селянський повстанський рух в Україні 1917-1921 років, red. Володимир Лободаєв, Книжковий Клуб „Клуб Сімейного Дозвілля", Харків 2017, s. 326-328.

Рум'янцев Вячеслав, Судова система в Українській державі гетьмана П. Скоропадського, „Вісник Академії правових наук України” 2001, 2 (25), s. 77-87.

Савченко Віктор, Махно, Фоліо, Харків 2005.

Сергійчук Володимир, Погроми в Україні: 1914-1920. Від штучних стереотипів до гіркої правди, приховуваної в радянських архівах, Видавництво ім. Олени Теліги, Київ 1998.

Сергійчук Володимир, Симон Петлюра і єврейство, wyd. 2, Київський національний університет імені Тараса Шевченка, Київ 2006.

Симон Петлюра. Статті, листи, документи, t. 4, red. Микола Іщенко, Видавництво ім. Олени Теліги, Київ 2006.

Сідак Володимир, Осташко Тетяна, Вронська Тамара, Полковник Петро Болбочан: трагедія українського державника, Темпора, Київ 2009.

Терещенко Юрій, Гетьманат Павла Скоропадського як прояв консервативної революизії, w: Гетьманат Павла Скоропадського. історія, постаті, контроверсії. Всеукраїнська наукова конференція 19-20 травня 2008 р., red. Владислав Верстюк, Видавництво ім. Олени Теліги, Київ 2008.

Тинченко Ярослав, Війська Ясновельможного Пана Гетьмана. Армія Української Держави, травень-грудень 1918 року, Темпора, Київ 2014 (Militaria Ucrainica).

Тинченко Ярослав, Офіцеерський корпус Армії Української Народної Республіки (1917-1921), t. 1, Темпора, Київ 2007. 
Тинченко Ярослав, Украӥнські зброцні сили. Березень 1917 - листопад 1918 р. (організація, чисельність, бойові діï), Темпора, Київ 2009.

Тинченко Ярослав, Хроніка бойових дій Армії УНР проти більшовиків у грудні 1918 - травні 1919 рр, w: Україна. 1919 рік. М. Капустянський „Похід украӥнських армій на Київ-Одессу в 1919 роиі”. Є. Маланюк „Уривки зі спогадів”. Документи та матеріали, red. Ярослав Тинченко, Темпора, Київ 2004.

Удовиченко Олександр, Третя Залізна дивізія. Матеріяли до історії Війська Української Народнъої Республики. Рік 1919, Червона Калина, Нью-Йорк 1971. Українська Держава (квітень - грудень 1918 року). Документи і матеріали. У двох mомах, t. 1 і 2, red. Валерій Смолій, Темпора, Київ 2015.

Українська Центральна Рада. Документи і матеріали. У двох томах, t. 2: 10 грудня 1917 p. - 29 квітня 1918 p., red. Владислав Верстюк та ін., Наукова Думка, Київ 1997.

Яневський Данило, Проект „Україна” або спроба Павла Скоропадського, Фоліо, Харків 2010.

Biog ram: Marek Bogdan Kozubel (Instytut Pamięci Narodowej) - ur. w 1987 r., doktor nauk humanistycznych w zakresie historii. W 2013 r. obronił na Uniwersytecie Mikołaja Kopernika w Toruniu rozprawę doktorską pt. „Dzieje Ukraińskich Strzelców Siczowych 1914-1920”. Absolwent Wydziału Nauk Historycznych oraz Wydziału Prawa i Administracji tejże uczelni. Jego zainteresowania koncentrują się głównie wokół tematów wojskowości i konfliktów zbrojnych pierwszej połowy XX w., ze szczególnym uwzględnieniem Europy Środkowo-Wschodniej, prawa wojennego, historii państwa i prawa oraz stosunków polsko-ukraińskich i rosyjsko-ukraińskich w wymienionym wyżej okresie; kontakt: mkozubel@wp.pl.

Author: Marek Bogdan Kozubel (Institute of National Remembrance) - born in 1987, PhD in history. In 2013, he defended his doctoral thesis ("Dzieje Ukraińskich Strzelców Siczowych 1914-1920") at the Nicolaus Copernicus University in Toruń. A graduate of the Faculty of Historical Sciences and the Faculty of Law and Administration of the same university. His interests focus mainly on military and armed conflicts in the first half of the twentieth century, with special emphasis on Central and Eastern Europe, military law, history of the state and law, and the Polish-Ukrainian and Russian-Ukrainian relations throughout the above-mentioned period. Contact: mkozubel@wp.pl. 